\title{
Who Bears the Pen? Relative Income and Gender Gap in Mortgage Signing Order ${ }^{1}$
}

\author{
Sumit Agarwal \\ NUS \\ Eric Rosenblatt \\ Fannie Mae
}

\author{
Richard Green \\ USC \\ Vincent Yao \\ Fannie Mae
}

\section{Jian Zhang \\ NUS}

June 6, 2015

\begin{abstract}
The major empirical challenge for estimating the driving force of the gender difference is the omitted variable bias because the proposed factor is usually intertwined with other observable and unobservable characteristics. This paper adopts a novel approach to tackle this identification problem and examines how the relative income defines gender roles in the context of mortgage signing order. We first document that men sign first $89 \%$ of the time when a mixed-gender couple applies for a housing loan. The signing order reflects purely behavioral preferences, as there is no difference in the legal rights or obligations of either the first or second borrowers. We show that relative income is the major determinant of the observed gender gap in signing order and we exclude other possible explanations such as discrimination, loan officer bias and social norms. To isolate relative income from differences in other dimensions, we compare the signing order of the mixed- and same-gender couples and find that the effects of relative income not only persists but also are fairly comparable between the two groups. Finally, we provide consistent macro-level evidences by both cross-sectional and dynamic analysis and show that gender gap in signing order is higher in states with larger gender wage gap and experiences a declining trend over time.
\end{abstract}

Keywords: Relative Income, Gender Bias, Mortgage Application, Household Finance JEL Classification Codes: A12, G02, J16, R2

\footnotetext{
${ }^{1}$ We benefited from the comments of Brent Ambrose, Gene Amromin, Zahi Ben-David, Souphala Chomsisengphet, Doug Evanoff, Nagpurnanand Prabhala, Tomek Piskorski, Wenlan Qian, Tarun Ramadorai, Amit Seru, and seminar participants at the National University of Singapore. The views expressed in this research are those of the authors and do not necessarily represent the policies or positions of Fannie Mae.
} 


\section{Introduction}

Gender difference is deeply rooted in our identity and widely documented by economists in disparate real-world economic activities. For example, though women have experienced substantial labor market gains in both participation and earnings, large gender gaps still remain (e.g. Blau and Kahn, 2006; Bertrand and Hallock, 2011). The divergence in earnings exists even in highly educated workers (Bertrand, Goldin, and Katz, 2010). We also observe gender gaps related to financial behaviors, including consumption and investment ${ }^{2}$. At the same time, experimental studies since the turn of the millennium have made great contributions to the evidence of gender differences in several traits, including risk attitudes, competition, altruism and cooperation. Croson and Gneezy (2009) and Niederle (2014) offer a complete review of related studies.

A number of explanations have been proposed to explain these observed gender differences. For instance, the most discussed source of gender gaps is discrimination, either taste-based or statistical, which traces back to the idea of gender identity norms (Akerlof and Kranton, 2000). Discrimination explains much of the gender gap in labor participation and earnings (Bertrand, 2011). Other studies attribute the gender gap to the difference in socio-economic status (Bartling, Fehr and Schunk, 2012), culture (i.e. Gneezy, Leonard and List, 2009; Guiso et al, 2008) and biological attributes such as testosterone levels (Maestripieri, Sapienza and Zingales, 2009). A recent paper (Bertrand, Kamenica and Pan, 2015) highlights the role of economic power and presents evidence that the relative income within households affects the wife's labor force participation. They show that when a wife earns more than a husband, she is about 1 to 2 percent less likely to work in the following year, or, if she continues to work, will work fewer hours in the following year. Remarkably, despite the lengthy literature explaining large gender gaps, very few papers succeed in establishing the cause of gender differences in a clean setting. The major difficulty is that many explanations for gender differences are intertwined and hence unobserved characteristics might be correlated with observables. This makes it hard to draw clean inferences about the effect of seemingly exogenous personal characteristics on outcomes.

\footnotetext{
${ }^{2}$ See, Sunden and Surette (1998), Schubert et al, (1999), Barber and Odean (2001), Agnew et al, (2008), Maestripieri, Sapienza and Zingales (2009) and Hoffman, Gneezy and List (2011).
} 
In this paper, we study gender difference in the setting of signing order on home mortgages. Examining signing order provides an ideal setting to study the gender effect on behavioral bias, as there are no differences in the legal rights or obligations of the first and second borrowers. We draw a random sample of 672,907 purchase-money owner-occupied home loans from a large national mortgage insurer. We start by documenting two simple facts of the gender gap: when a mixed-gender couple applies for a loan, the man earns more $79 \%$ of the time and the man signs first $89 \%$ of the time.

We evaluate the power of different hypotheses shown in the literature in explaining the gender gap of signing order. Our results lend strong support to the relative economic power hypothesis, that is, the signing order is presumably determined by the relative income within the household. We go on to conduct tests to exclude other hypotheses. We first show it is not due to a loanofficer specific effect, which means that our results are not driven by some loan officers who only ask the man to sign first. Another possibility is that there may be a prevalence of discrimination against females among loan officers so that they always hand over the contract first to the man. We show this is also not the case. Lastly, males may sign first simply because of social norms that men are supposed to know more about finance and serve as the protector of the family from legal issues. We use marital name change as proxy for the socio culture norms with respect to gender equality and show that the role of relative economic power is still robust.

Similar to previous empirical studies, so far we only establish the correlation between relative income and gender gap in signing order because income gap is very likely to be a reflection of other factors, e.g. it may be due to the gender identity norms as suggested in Bertrand, Kamenica and Pan (2015). We argue that the presence of omitted variable problem makes the identification task arduous. In this paper we develop an identification strategy to overcome this problem. We rely on same-gender group and compare the signing order on mortgages of same-gender couples to different-gender couples. The intuition is that same-gender couples (male-male pair or femalefemale pair) cannot suffer gender bias, and thus make for a clean control group. Though couples with common genders make up only 1.8 percent of our sample, the same-gender sample is still large enough (11,971 observations) to ensure estimation power. Our results indicate that 
economic power still serves as an important determinant of signing order of same-gender couples, but that alone cannot explain the entire difference in signing order of different-gender couples.

We also examine cross-sectional and dynamic determinants of gender bias in signing order. First, our results reveal that gender bias in signing order is positively correlated with the gender wage gap across states. States where men have more economic power are also states where men are more likely to sign first. But it is also the case that states with attitudes that produce greater economic power for men are also states where men are more likely to sign first. Second, we find differences in political attributes help explain differences in signing order across states. The different political attitudes vis-à-vis gender roles can reflected in the voting for the Payroll Fairness Act. This Act aims to reduce the gender gap in wages but has failed to pass four times since 2010 owing to the opposition of Republican members in the Congress. We would therefore expect gender bias in signing order to be more pronounced in states that vote for the Republicans. Using the 2004 Presidential Election Campaign, we show that states with stronger gender bias in signing order are also "redder". Finally, we note that Goldin (2014) has determined that economic differences between men and women are converging, especially in earnings. In light of this, we could expect the gender gap in signing order to attenuate across time. Our results confirm that it does.

Our paper contributes directly to the literature that explores the causes of gender differences ${ }^{3}$. Discrimination is among the most popular explanations for gender gaps. The micro-foundation of such discrimination can be found in the identity model developed by Akerlof and Kranton (2000), where one's identity directly enters the utility function. Socio-economic status and culture have also been related to gender gaps. For example, Bartling, Fehr and Schunk (2012) show that the gender gap in competiveness is smaller for children from lower socio-economic backgrounds. Gneezy, Leonard and List (2009) compare the gender gap in competiveness for patriarchal Maasai in Tanzania and the matrilineal Khasi in India and find that women are at a large disadvantage in Maasai while being at an advantage in Khasi.

\footnotetext{
${ }^{3}$ The literature on gender gap is comprehensively reviewed in the economics (Eckel and Grossman, 2008; Croson and Gneezy, 2009; Bertrand, 2011)
} 
In a recent paper, Bertrand, Kamenica and Pan (2015) argue relative economic power within household matters in the marriage and labor markets. They present evidence that couples in which women earn more than men are less likely to participate in future labor market and more likely to divorce or separate. However, they cannot distinguish whether this is explained by the role of economic power or social norms, and thus choose the gender identity norms argument. With the help of same-gender couples, we are able to have a cleaner identification to eliminate the social norms argument and characterize the important role of relative economic power in determining observed gender gaps within households, supporting their argument. As far as we know, our paper is the first among gender studies to use the setting of same-gender couples to shed light on the mechanism of how relative economic power defines gender roles within households.

Our paper is closely related to studies that empirically verified gender differences in financial decision-makings. We document that the man signs first $89 \%$ of the time when a differentgender couple applies for a housing loan. This is similar to the findings of gender gap in stock trading (Barber and Odean, 2001) and defined contribution plan investment (Sunden and Surette, 1998; Jianakoplos and Bernasek, 1998). The paper also broadly contributes to the large body of economic literature that has found evidence of gender gaps in lotteries (Byrnes, Miller and Schafer, 1999; Croson and Gneezy, 2009; and Eckel and Grossman, 2008), school test scores (Blau and Kahn, 2006; Goldin, Katz, and Kuziemko, 2006; Niederle and Vesterlund, 2010; Pope and Sydnor, 2010) and driving (Dohmen and Falk, 2011).

The paper proceeds as follows. Section 2 presents data sources and descriptive statistics. Main results appear in Section 3 while Section 4 displays macro evidence and robustness tests. Section 5 concludes.

\section{Data Sources and Descriptive Statistics}

\section{A. Data}

We use in our analysis a unique and proprietary dataset obtained from a large national mortgage guarantor that guarantees more than $25 \%$ of residential mortgages in the United States. Our sample contains 672,907 purchase money owner-occupied housing loans, which is a random and 
representative sample of the insurer's borrower pool. The time period spans 2004 to 2014. All the loans are originated by a variety of different lenders, and are "conventional". Specifically, we do not include "jumbo" loans, which are usually in an amount above conventional conforming loan limits ${ }^{4}$. We also exclude government and subprime loans, whose borrowers tend to have lower incomes and less established credit records. For each mortgage, the number of applicants can vary from a single borrower to several ${ }^{5}$. Because our interest lies in the behaviors of couples, we only focus on those loans with two borrowers. Such borrowers represent about two-thirds of the full sample. We exclude possible parent-child pairs by limiting the sample to those loans where the age difference of couples applying to be less than 18 years. Privacy laws prevent us from identifying sensitive information such as name, social security number or specific address of any borrower.

The gender composition of the two borrowers allows us to classify the mortgage sample into two groups: different-gender pairs and same-gender pairs. We are interested in differences in signing order among different gender pairs, who make up 98.2 percent of our sample. We shall use the 1.8 percent of our sample that is same-gender couples to identify differences in signing order arising from characteristics other than gender. While only around $1.8 \%$ of mortgages are to couples of the same gender ${ }^{6}$, out underlying population of mortgages is sufficiently large that we can obtain sharp coefficient estimates on determinants of signing order. This allows us to determine how people self-select first signer in the absence of a gender difference. It is critical for our identification strategy by using different-gender couples, because it offers us a cleaner setting to identify how relative economic authority trades off against other factors in the decision to sign first. In the online Appendix, we also use the same-gender sample to create an "economic authority" index, which predicts first signer based on the relative age, income, and historical credit record of the two borrowers (taken from the credit reports submitted by the borrowers).

\footnotetext{
${ }^{4}$ The largest loans since 2006 in our sample never have balances of more than $\$ 417,000$.

${ }^{5}$ Our results remain unchanged if we include these loans in our analysis.

${ }^{6}$ The proportion of same-gender couples in our sample, $1.8 \%$, is consistent with the 2013 National Health Interview Survey (NHIS), in which $1.6 \%$ of respondents identify themselves as gay or lesbians. http://www.cdc.gov/nchs/data/nhsr/nhsr077.pdf
} 


\section{B. Summary Statistics}

We report the summary statistics of credit and demographic variables in Table 1. Panel A shows the credit and demographic variables for all applicants in our full sample. The average and median ages in our sample are 42 and 39. Around $80 \%$ of applicants have some college education. The mean and median FICO scores are 760 and 773 , which is high relative to population statistics in previous studies (e.g. Agarwal, Chang and Yavas, 2012). The mean and median income of households in our sample is $\$ 4,644$ and $\$ 3,995$ monthly $(\$ 55,728$ and $\$ 47,940$ annually), which is quite comparable to the estimates reported by the Census Bureau for the US as a whole ${ }^{7}$.

Panel B provides an overview of the characteristics for all first signers. We observe a striking gender bias in the signing order: male borrowers sign the applications first $89 \%$ of the time. The gender difference in signing order is economically significant compared to what is documented in the literature. For example, Niederle and Vesterlund (2007) examine whether men and women of the same ability differ in their choice of a competitive environment. Their result show that $73 \%$ of the men select more competitive environments, while only $35 \%$ of the women make such choices. The estimates in Bertrand, Goldin and Katz (2010) show that, while male and female MBAs have nearly identical income following MBA completion, the gaps in annual earnings expand considerably as careers progress, reaching almost $60 \log$ points at ten to 16 years after MBA completion ${ }^{8}$. As shown in Panel B, the mean age and FICO for the first signers are 40 and 759. $81 \%$ of first signers have at least attended college. The mean monthly income of first signers is $\$ 6,511(\$ 78,132$ annually) and is much higher than the population mean $(\$ 4,644$ or $\$ 55,728$ annually) as described in Panel A. Moreover, the income distribution among first signers is positively skewed with the median monthly income $\$ 5,484$ (\$65,808 annually), which is not reported.

\footnotetext{
${ }^{7}$ For estimates of US Census Bureau, please refer to http://www.census.gov/prod/2013pubs/p60-245.pdf.

${ }^{8}$ Other estimates include that men trade 45 percent more than women in the stock market (Barber and Odean, 2002) and female high-level executives earned about 45\% less than men (Bertrand and Hallock, 2001).
} 
To explore the determinants of signing order between the two signers, we define a series of binary variables to compare the first with the second signer and present the statistics in Panel B. For example, Higher Income Dummy is a dummy indicating whether the first signer earns more than his/her co-signer, while Same Surname Dummy shows whether the two signers have the same surname (The detailed definition is shown in Appendix A). We find a large difference in earnings between the first and second signer. The first signer earns more income than the cosigner $79 \%$ of the time, which provides the first descriptive evidence that the member of the couple with more economic power is more likely to sign first.

Of course, income may simply be correlated with other variables that actually determine signing order. We therefore go on to examine other variables, such as age, personal credit rating and education. The intuition is that those who are more sophisticated in handling banking issues, are better educated or have better credits rating are more likely to take the lead on applying for a mortgage, and therefore sign when applying for the mortgage. Nevertheless, we find the first signer is not significantly older, more creditworthy or better educated than the second signer ${ }^{9}$. The relative disadvantage of first signer in age, credit rating and education lend support to our relative income hypothesis that it is the higher income that really determines the signing order. As a reflection of increasing gender equality, more and more married women choose to deviate from the long-standing tradition of changing their maiden surname to their husband's. We also report the summary statistics for the variable Same Surname Dummy. In our sample, the men and women in the couple share the same surname $89 \%$ of the time, consistent with the estimates in Goldin and Shim (2004). The average combined loan to value ratio (CLTV) is at $81 \%$ and the average debt to income ratio (backend) is at $36 \%$. The average note rate of the mortgages is around $5.13 \%$.

To further validate the economic advantage of first signers, we design a test or the top 10 lenders in our sample to see if there is a consistent concurrence between signing first and earning higher income (income rule) or having higher FICO score (FICO rule). We construct two variables,

\footnotetext{
${ }^{9} \mathrm{~A}$ few words of caution are warranted when interpreting the results here. While the estimate shows that first signer is younger, more creditworthy and better educated most of the time, this does not reveal any information about the magnitude of the difference and they may be in the age (FICO or education) bucket (e.g. the age of the first and second signer is 40 and 39 respectively).
} 
Income_Rule and FICO_Rule, to determine the power of higher income and higher FICO for determining signing order. Income_Rule is a dummy variable that is equal to one if the first borrower makes higher income than his/her co-borrower, zero otherwise. FICO_Rule is a dummy variable that is equal to one if the first borrower has a higher FICO score than his/her coborrower, zero otherwise. If some lenders assign the first signature to the member of the household with the higher income, the mean value of Income_Rule for those lenders should be very close to one. Results are shown in Online Appendix Table 1. Columns 4 and 5 suggest that the signing first is highly congruent with earning higher income but not with having higher FICO score.

\section{[Insert Table A1 Here]}

To test the legitimacy of using the same-gender sample as a counterfactual, same-gender couples applying for mortgages must be observationally similar to different-gender couples. We thus present summary statistics conditional on the gender composition of the two borrowers -- sameor different-gender -- in Panel B. We observe little systematic difference in these observable characteristics of first signers in the two samples. The incomes and FICO scores are similar in both groups. With regards to the comparison within borrower pairs, there is also little difference between the two groups. Most importantly, first signers in both samples are earning more income than their co-borrowers, which again confirms our relative economic hypothesis. High Income Dummy, defined as whether the first signer has higher income, is also quantitatively similar between the two groups ( 0.78 for same-gender vs. 0.79 for different-gender). Next, we move on to examine whether same- and different-gender couples are applying for similar mortgage contracts. Results suggest that the key terms in the contracts of both samples, like combined loan to value ratio, back end ratio and mortgage note rate, are essentially the same. Indeed, despite the large size of our sample, they are not statistically different at the 95 percent level of confidence.

[Insert Table 1 Here]

\section{Main Results}


Panel B of Table 1 provides prima-facie evidence for a cause of the observed gender gap in signing order: the first signer tends to earn more income. In this section, we formally present evidence pertaining to the relative income hypothesis. We first consider two factors, income and age, and use a sorting approach to examine whether men are more likely to serve as the first signer simply because they are older or earn higher income. Then we control for gender differences among other dimensions and analyze the contribution of relative income to signing order using multivariate regression. We also exclude other possible channels like loan bias, discrimination, as suggested in the literature. To sharpen our results, we compare the results of the different gender estimates using same-gender couples.

\section{A. Gender gap and relative economic authority}

We investigate how age and income affect signing order by sorting borrower pairs into age and monthly income categories conditional on genders. Our cross-tabs allow us to characterize how signing-first probability is influenced by age and income. We wish to know, for example, given the man's age, how the change in woman's age will drive the probability that the man signs first. If age or income really matters, we should expect to observe a monotonic increase/decrease in the signing order.

We first classified all different-gender couples based on the age combination of male and female. The six age categories we consider are (i) <=25; (ii) 26 to 35; (iii) 36 to 45; (iv) 46 to 55; (v) 56 to 65 ; (vi) $>65$. Panel A of Table 2 reports the matrix, with each cell indicating the probability of male signing first for that particular age-pair. We do not observe a monotonic effect of being older on being the first signer, in other words, relative difference in age cannot effectively explain the probability of signing first. For example, in Column 1 when we fixed the age of female to be between 46 and 55, we find the probability of male signing first does not exhibit any increasing or decreasing trend as the male's age rises from the top to the bottom. Results are similar when we condition on the other age bucket or the age of male. Thus, the signing order cannot be captured by the relative age between genders. 
We use similar approach to investigate the role of economic authority, namely earning higher income, in determining the order. We consider nine income categories (i) $<=\$ 1 \mathrm{~K}$, (ii) $1 \mathrm{~K}$ to $2 \mathrm{~K}$, (iii) $2 \mathrm{~K}$ to $3 \mathrm{~K}$, (iv) $3 \mathrm{~K}$ to $4 \mathrm{~K}$, (v) $4 \mathrm{~K}$ to $5 \mathrm{~K}$, (vi) $5 \mathrm{~K}$ to $6 \mathrm{~K}$, (vii) $6 \mathrm{~K}$ to $7 \mathrm{~K}$, (viii) $7 \mathrm{~K}$ to $10 \mathrm{~K}$ and (ix) $>10 \mathrm{~K}$ and report the gender gap in Panel B of Table 2. Interestingly, we observe a strictly and positively monotonic relationship of earning higher income and signing first on the mortgage contract. For instance, when we fix the monthly income of female at the category which contains the sample mean (between $4 \mathrm{~K}$ and $5 \mathrm{~K}$ ), the probability of male signing first increases monotonically from $50 \%$ to $96 \%$ as men's income rises from the bottom to the top category. Similarly, conditional on men's monthly income being between $4 \mathrm{~K}$ and $5 \mathrm{~K}$, the probability of female signing first increases from $2 \%$ (100\% minus $98 \%)$ to $39 \%(100 \%$ minus $61 \%)$ as women's income rises from the left income category $(<\$ 1 \mathrm{~K}$ per month) to the right category (> \$10K per month).

\section{[Insert Table 2 Here]}

Searching in the marriage market usually leads to matching with similar partners in equilibrium. Previous studies (e.g. Jepsen and Jepsen, 2002) confirm this by showing empirically that members of married couples are alike with respect to both labor-market and non-labor-market traits (e.g. age, education and hourly earnings). So the main concern with the cross-tab approach is that the couples are usually similar with each other in terms of age and income, so there may be too few observations for some extreme age/income pairs to draw valid inference. To address the problem of limited observations, we present the joint age and income distribution on the Online Appendix Table 2. Not surprisingly, we find that the distribution is not evenly distributed across all pairs but more concentrated in the pairs on the diagonal. This confirms the similar matching argument. However, if we look at the distributions for pairs far from the diagonal, the observations are still sufficiently large to draw inferences.

Note that, by design, there are equal numbers of men and women in the sample. If we look at the age buckets, we see that men are older $23 \%$ of the time, women for $6 \%$ of the time, and the same age for $71 \%$ of the time. With respect to income, we see that men earn higher income $69 \%$ of the time, women earn income $19 \%$ of the time, and the remaining $12 \%$ couples earn roughly the 
same income. ${ }^{10}$ Hence, the preponderance of male first signing may simply reflect the fact that men have higher incomes, within a couple, than women.

[Insert Table A2 Here]

Before proceeding with our main tests, we examine whether the relative income hypothesis can be inferred through income distribution plots. Specifically, we plot the income distribution for different genders separately conditional on the signing order between genders, depending on whether the first signer is male or female. Panel A of Figure 1 presents a plot for loans with male as the first signer while Panel B of Figure 1 shows for the cases when female signs first. The plot confirms the important role of relative economic authority in determining the gender gap; regardless of the gender for the first signer, the first signer's income tends to be higher.

[Insert Figure 1 Here]

\section{B. The role of relative income}

In this section, we explore whether the relative economic power can explain the gender gap in signing order after controlling for other observed gender differences. Considering a differentgender couple $i$ is applying for housing loan in state $j$ at year $t$, let the $D$ (ManSigningFirst $)_{i, j, t}$ be a binary variable that equals to 1 if the husband signs first rather than his wife. We consider a linear probability model as the baseline specifications in Table 3:

$$
\begin{aligned}
& D \text { (ManSigningFirst })_{i, j, t} \\
& =\alpha_{0}+\alpha_{1} D(\text { Higher Income })_{-} M e n_{i, j, t}+\alpha_{2} D(\text { Older Age })_{-} M e n_{i, j, t} \\
& \left.+\alpha_{3} D \text { (More Autos }\right)_{-} M_{\text {en }}{ }_{i, j, t}+\alpha_{4} D(\text { Higher FICO })_{-} M_{\text {en }} n_{i, j, t} \\
& +\alpha_{5} D \text { (Higher Education)_Men } n_{i, j, t}+\alpha_{6} \text { Age_Men }_{i, j, t} \\
& +\alpha_{7} \text { Auto Number_Men }{ }_{i, j, t}+\alpha_{7} \text { Education_Men } n_{i, j, t}+\alpha_{8} \operatorname{Ln}(\text { FICO)_Men })_{i, j, t} \\
& +\alpha_{9} \operatorname{Ln}(\text { Income })_{-} M_{e n} n_{i, j, t}+\alpha_{10} X_{j}+\alpha_{11} Z_{t}+\varepsilon_{i, j, t}
\end{aligned}
$$

${ }^{10}$ The $12 \%$ denotes the male and female borrowers' income are in the same category on the diagonal. 
Where $D$ (Higher Income $)_{-} M n_{i, j, t}$ is the binary variable indicating the husband earns more than his wife, D(Older Age)_Men $n_{i, j, t}, D(\text { More Autos })_{-}$Men $_{i, j, t}$, D(Higher FICO )_Men and D(Higher Education )_Men $n_{i, j, t}$ are also dummies indicating whether the husband is older, have more auto trade line, higher FICO and education than his wife as of mortgage application. Age_Men $_{i, j, t}$, Auto Number_Men $n_{i, j, t}$, Education_Men $n_{i, j, t}, \quad \operatorname{Ln}(F I C O)_{-}$Men $_{i, j, t}$, and $\operatorname{Ln}(\text { Income })_{-} M e n_{i, j, t}$ are the age, auto trade line number, education dummy, the logarithm of FICO and income for the husband of the couple i. $X_{j}$ and $Z_{t}$ include the state and year fixed effect. Standard errors are clustered by state. Our coefficient of interest is $\alpha_{1}$ and a positive estimate of $\alpha_{1}$ means that when the husband earns more than his wife, he is more likely to be the first signer. In the baseline specification, the point estimate shows that is 0.262 and statistically significant at $1 \%$ level.

The observed gender gap in signing order may also be a reflection of gender difference in other dimensions. So we include in Column (2) four relative variables that control for the difference in age, auto trade line, FICO and education within the couple. All four variables take the form of binary choice indicating whether the husband possess certain advantages over the wife. The estimate of $\alpha_{1}$ remains stable at 0.256 and is still statistically significant $(\mathrm{p}<0.01)$. Another issue is that the actual level of the demographical and credit variables may also affect the likelihood of signing first on the mortgage. We further control for the husband's age, auto trade line number FICO and education in Column (3). The estimate of $\alpha_{1}$ decreases somewhat to 0.200 but is statistically significant $(\mathrm{p}<0.01)$.

In column (4), we also include the state and year fixed effect to absorb the common variation in time and across locations. The estimate of $\alpha_{1}$ decreases slightly to 0.194 and is highly significant ( $\mathrm{p}<0.01$ ). The magnitude of $\alpha_{1}$ is little affected as we include more controls across all columns. The stability of the estimates across specifications suggest that the observables characteristics are relative representative of unobservable and thus omitted variable bias is less of concern for our estimate of $\alpha_{1}$ (e.g. Altonji et al, 2005). 
The economic magnitude of the estimate is also significant. For example, the coefficient estimate in Column (4) tells us that a 10 percentage increase in the probability that the husband earns more than the wife increase the likelihood that he signs the mortgage first by 1.94 percentage points. In other words, one standard deviation rise in the probability that the husband earns more than the wife increases the likelihood that he signs the mortgage first by $8 \%$.

\section{[Insert Table 3 Here]}

\section{Loan officer bias and discrimination}

One important issue pertaining to identification is the signing process involves a third party: the loan officer. Therefore, it is also possible that the observed prevalence of male signing first is partly or wholly driven by the behavior of loan officers. We consider two possibilities. The first one is that discrimination against female borrowers is a widespread phenomenon among loan officers, so that when they lead the signing process they ask the male to sign first. Evidence from the literature is fairly mixed: some studies (e.g. Peterson, 1981) suggest that no systematic pattern of prejudicial sex discrimination was found in consumer lending, while others (e.g. Alesina, Lotti and Mistrulli, 2013; Muravyev, Talavera and Schafer, 2009) find that banks do discriminate against female in extending loans. The other possibility is that loan officers are inherent believers of the social and cultural norms that man is the natural protector of the family. With biased attitudes towards females, they may simply hand the contract to the man first. In this part, we explore whether loan officers, owing to either discrimination or bias, drive the gender gap of signing order.

We first argue that discrimination against the female is less of a concern for our setting. We posit that if lenders discriminate against women in general, they would avoid extending mortgages to female-female couples, relative to other types of couples. However, we do observe relative large number of female-female couples in our sample (6,170 observations). We further address the issue by comparing the demographics and mortgage characteristics between loans that are signed first by male ( $89 \%$ of the different-gender sample) and female (11\% of the different-gender 
sample). The results are reported in Table 4. Under the discrimination argument, we hypothesize the loan officers would extend less favorable terms for loans that are signed by the female, for example, requiring higher LTVs or charging higher rates. However, we find little evidence that the key terms of mortgage contracts differ significantly between the two types of loans. The distribution of CLTV, backend rate and note rate in Figure A1-3 also confirm this.

[Insert Table 4 Here]

[Insert Figure A1-3 Here]

We next examine whether the results in Table 3 are driven by some loan-officers exhibiting bias towards females, that is, some loan officers choose to hand over the contract first to the male not out of discrimination, but because of the social norms. Our identification strategy is based on the notion that loans with male signing first should represent a large proportion among all processed by the biased loan officers. So we first classify all loans into two types based whether the first signer is male and female the signing order infer the preference of loan officers towards gender by looking at the composition of these two loan types among all their loans.

The baseline specification in Column (1) of Table 5 is similar to Column (4) of Table 3 except that we further control for the loan officer fixed effects here. The estimated impact of $D$ (Higher Income )_Men ${ }_{i, j, t}$ on ManSigningFirst ${ }_{i, j, t}$ is 0.193 and statistically significant $(<0.01)$. The magnitude is quite stable compared to that in the Column (4) of Table 3, which alleviate the concerns about the omitted variable problems. We define a loan officer to be biased if, among all loans they handled, the proportion of loans with male signing first is above the mean level (89\%) and unbiased if below. In Column 2 and 3, we conduct subsample analysis using the same specification for loans under biased and unbiased loan officers. The estimated impacts of earning higher income are consistently positive (from 0.191 to 0.237 ) and highly significant $(\mathrm{p}<0.01)$. More importantly, the estimates of $\alpha_{1}$ do not vary much across samples. Overall, the results suggest that the gender gap in signing order is not driven by the behaviors of loan officers. 
[Insert Table 5 Here]

\section{Surname Retention at Marriage}

It has been a tradition for married women to follow their husband's surname and few women deviated from this custom throughout U.S. history (Stannard, 1977). As a way of seeking equality to man, more and more married women decide to preserve their own surname ${ }^{11}$. According to the estimates in Goldin and Shim (2004), the fraction of all U.S. College graduate women who kept their surnames upon marriage rose from about 2 to 4 percent in 1975 to just below 20 percent in 2001. In this section, we consider the action of marital name change as a proxy for socio-cultural values and investigate whether the relative income hypothesis is a simple reflection of the heterogeneity in socio-cultural values.

We cannot cleanly identify the marital surname change because we always observe the current married surname rather than the maiden surname of women in the sample. We try to identify the action of not following husband's surname at marriage by matching the surnames of the couple. We assume that for couples with different surnames, the wife preserves the identity of her own surnames (there may be rare instances where both halves of the couple brought the same surname to the marriage). On the other hand, for couples with same surname, the wife is highly likely to have quit her surname and followed the husband's at marriage. We neither know who these are or how they feel about self-identity. We argue this does not undermine our identification but biases down our estimation. Couples wife preserves her surname should enjoy greater gender identity within them, relative to others.

The results are presented in Table 6. In Column (1), we include a control for the gender inequality using a binary variable Same Surnames that equals one if the different-gender couple has the same surname and zero otherwise. All other specifications are the same as in Column (1) of Table 5 except for adding proxy for the gender inequality. The coefficient on this dummy variable is positive and statistically significantly, which is consistent with the notion that the

\footnotetext{
${ }^{11}$ Prominent feminists are also forming league to help promote this preservation.
} 
husband is more likely to be the first signer when there is greater level of gender inequality within the couple. However, our estimate effect of D(Higher Income)_Men $n_{i, j, t}$ on ManSigningFirst $_{i, j, t}$ is mostly unaffected and remains statistically significant $(\mathrm{p}<0.01)$. In Columns 2 and 3, we turn to the subsample analysis by dividing the full sample based on whether the couple has the same surname. The estimates of $\alpha_{1}$ again are barely affected and remain statistically significant in both samples. Not surprisingly, income tends to be the most important determinant of signing order, but we now have evidence that socio-cultural attitudes matter as well.

[Insert Table 6 Here]

\section{E. Exploring gay couples}

Although we use changing surname at marriage to proxy for socio-culture values, social and cultural norms are often entangled with other effects so that it is difficult to quantitatively pin down and have a direct measure. That is why it has been a great challenge to empirically rule out the effect of social and cultural norms when scholars try to explain the underlying mechanism of observed gender gaps. Not surprisingly, social and cultural norms with respect to gender identity are often relied on as a final resort in previous literature for explaining behavioral differences (e.g. Bertrand, Kamenica, and Pan 2015). In this section, we adopt a novel approach to address this empirical challenge. Specifically, we distinguish the social and cultural norms explanation from our relative income hypothesis using same-gender couples as the control group; such couples, by definition, should be free of gender bias.

We consider an alternative specification to examine how relative income within the household affects the signing order. We argue that if the relative income really matters for the signing order between genders, we should observe the same pattern of for the same-gender groups. Given an individual $i$ living in state $j$ is applying for the mortgage at year $t$, let $D$ (Signing First) $)_{i, j, t}$ be a binary variable that equals to 1 if the individual signs first rather than its co-signer. The unit of observation here is the borrower rather than pairs in Section B-D. We estimate a linear 
probability model as the baseline specifications for both the same- and different-gender samples in Table 7:

$$
\begin{aligned}
& D(\text { SigningFirst })_{i, j, t} \\
&=\beta_{0}+\beta_{1} D(\text { Higher Income })_{i, j, t}+\beta_{2} D(\text { Older Age })_{i, j, t} \\
&+\beta_{3} D(\text { More Autos })_{i, j, t}+\beta_{4} D(\text { Higher FICO })_{i, j, t} \\
&+\beta_{5} D(\text { Higher Education })_{i, j, t}+\beta_{6} \text { Age } i_{i, j, t} \\
&+\beta_{7} \text { Auto No } o_{i, j, t}+\beta_{7} \text { College } e_{i, j, t}+\beta_{8} \operatorname{Ln}(\text { FICO })_{i, j, t}+\beta_{9} \operatorname{Ln}(\text { Income })_{i, j, t} \\
&+\beta_{10} X_{j}+\beta_{11} Z_{t}+\varepsilon_{i}
\end{aligned}
$$

Where $D(\text { Higher Income })_{i, j, t}$ is the binary variable is the individual earns more than his/her co-signer, $D(\text { Older Age })_{i, j, t}$ and $D(\text { More Autos })_{i, j, t}$ and $D(\text { Higher FICO })_{i, j, t}$ and $D$ (Higher Education $)_{i, j, t}$ are also dummies indicating whether the individual is older, have more auto trade line, higher FICO and education than the co-signer as of mortgage application. Age $_{i, j, t}$, Auto $\mathrm{No}_{i, j, t}$, College $_{i, j, t}, \operatorname{Ln}(F I C O)_{i, j, t}, \operatorname{Ln}(\text { Income })_{i, j, t}$ are the age, auto trade line number, education, FICO and income for the individual i. $X_{j}$ and $Z_{t}$ include the state and year fixed effect. Standard errors are clustered. Our coefficient of interest is $\beta_{1}$ and a positive estimate of $\beta_{1}$ means when an individual earns more than the co-signer, he /she is more likely to be the first signer.

Results are reported in Table 7 with panel A for the male-male pairs and Panel B for femalefemale pairs. In Column 1, we only include the dummy for higher income, Higher Income Dummy and add more controls in Column 2 to 5, namely the absolute and relative credit and demographics, fixed effect and social values. The estimated effects of $D$ (Higher Income $)_{i, j, t}$ on SigningFirst $t_{i, j, t}$ are positive and statistically significant $(\mathrm{p}<0.01)$ across specifications and for all three samples: gay, lesbian and different-gender couples.

More importantly, the economic magnitudes of the effect are also comparable between sameand different-gender couples. In our preferred specification (Column 5) in Panel A and B, an 10 percentage increase in the probability that the individual earns more than the co-borrower 
increase the likelihood that he/she signs the mortgage first by 3.98 and 3.88 percentage points for the gay and lesbian couples respectively. The estimate collars the estimate of 3.93 for the different-gender sample in Column 5 of Panel C. This provides strong evidence in support of our relative income hypothesis: who earns more income tends to serve as the first signer. It also shows that the income variable is not being driven by unobserved tastes for signing order.

[Insert Table 7 Here]

\section{Macro Evidence and Robustness}

\section{A. Cross-section}

The gender wage gap has been a long-standing puzzle in the labor economic literature (e.g. Becker, 1985; Katz and Murphy, 1992; Blau and Kahn, 1997; Bertrand and Hallock, 2001; Aizer, 2010). In this section, we view the state-level gender wage gap as a macro presentation of the relative income within the households and provide two cases of cross-sectional macro-level evidence that are consistent with our relative economic power hypothesis.

We first estimate the state-level gender bias in signing order in our full sample of differentgender couples and plot it against the gender wage gap in that state. Figure 3 presents the plot. Interestingly, we find a strong and positive correlation with coefficient of the correlation 0.44 , which suggests that states with a greater tendency for males to sign first tend to be states with a larger gender income gap. The result supports the notion that women get more actively involved in financial transactions such as mortgage signing in states where they enjoy higher economic status, as indicated from a smaller gender wage gap.

\section{[Insert Figure 3 Here]}

In the United States, there are strong and consistent voting patterns among states. States such as Texas and Arizona that customarily vote for Republican candidates are colloquially known as red states; those like California and Washington that vote for Democrats are blue states. As 
shown in Gelman (2009), the general principle is that poorer states tend to vote red and richer states are bluer. At the same time, Democrats and Republicans have been debating policy over promoting equal pay between genders for a long time. The most recent example is the Paycheck Fairness Act, which aimed to reduce the gender gap in wage but has failed four times since 2010 due to the opposition of Republicans. We explore this voting pattern in our setting and plot a scatter diagram between gender gap in signing order and percentage of votes for George W. Bush in the 2004 Presidential Election (Figure 4). Consistent with our relative economic power hypothesis, we find that states with stronger gender bias in signing are also "redder". The coefficient of the correlation between the two is 0.77 . The eight states with the lowest signing order bias all voted Democratic. Twelve of the fourteen states with the highest bias voted for the Republican.

\section{[Insert Figure 4 Here]}

\section{B. Dynamics}

We next study the dynamics of the observed gender gap in signing order. The changes in women's and men's work lives since the mid-twentieth century have been considerable. The best known facts about such changes include women's rising labor force participation and also the narrowing of the gender wage gap. These trends of convergence in earnings for men and women is also widely documented and explained in the very recent literature ${ }^{12}$ (e.g. Bacolod and Blum, 2010). Therefore, under the relative income hypothesis, we would expect to observe a declining trend for the gender gap in signing order. In Figure 5, we plot the estimated gender gap in signing first by year during our sample period from 2004 to 2014 . The plot confirms the relative economic power hypothesis: the gender gap in signing first narrows with the convergence of gender wage gap.

\section{[Insert Figure 5 Here]}

\footnotetext{
${ }^{12}$ According to Goldin (2014), the converging roles of men and women are among the grandest advances in society and the economy in the last century
} 


\section{Robustness Test}

We perform two falsification tests to study the robustness of our results. Firstly, to confirm that what we document is really gender bias instead of bias in other dimensions, we assign gender to each applicant in the different-gender sample using a random number generator. Then we reestimate the specification in Column 1 of Table 6. The results are reported in Column 1 of Table 8. The estimate of $D(\text { Higher Income })_{-}$Men $_{i, j, t}$ on ManSigningFirst ${ }_{i, j, t}$ is basically zero (0.001(t=0.78)) and becomes no longer significant. To validate our emphasis on the role of relative income within the household, we also randomly assign the higher income within each couple and repeat the analysis in Column 2. Again, we find the estimates decrease to nearly zero and highly insignificant. We no longer observe the role of relative economic power in predicting the signing order when randomly assigning gender or income. This suggests that we are not identifying spurious variation.

\section{[Insert Table 8 here]}

\section{Conclusions}

This paper uses a large and proprietary dataset to empirically test the gender gap in the context of residential mortgage signing order. The mortgage signing allows us to cardinally measure something of broad importance: how men and women behave in the face of a joint financialrelated decision, captured under almost ideal test conditions. Neither the principals nor the test administrators know they are being tested, and the outcome has no meaning beyond its ordering. Signing first also enables us to have a clean identification to examine gender gap in behavioral preference since both borrowers take the same obligation for the mortgage.

We document a large gender gap in mortgage signing order: male borrowers sign first $89 \%$ of the time. To explore the underlying mechanism that drives the observed gender gap, the paper considers various explanations proposed by previous studies. We empirically establish that the relative economic power defines the gender identity in the setting of mortgage signing order and 
exclude effects induced from loan officer bias, and discrimination. Including cultural norms does not eliminate the explaining power of relative economic hypothesis. To distinguish the relative income influence from other factors, we explore a more precise identification of determinants of signing order by looking at same-gender pairs, which are free of gender effects. We find that the effect of relative income on signing order remains little changed, no matter we look at samegender or different-gender couples. We also provide macro-level evidence to support the relative economic power hypothesis: states with greater tendencies for males to sign first tend to be states with gender wage gap and with stronger republican representation. The dynamics of observed gender gaps in signing first also coincides with the convergence of the gender gap in wage across time.

Our study makes contributions to the literature in two ways. First, we are the first study to take advantage of gay couples in the gender literature and distinguish the hard-to-quantified social norm effect, which is usually entangle with other factors. Second, we cleanly identify the role of relative income in defining gender identity, especially in financial decision-making process. In future work, we would like to understand the role of relative economic power in broader settings. We are particularly curious about whether this effect will grow weaker in the long-run with the rapid convergence of men and women' roles in the broader economy. 


\section{References}

Agarwal, Sumit, Yan Chang and Abdullah Yavas, 2012. "Adverse Selection in Mortgage Securitization." Journal of Financial Economics 105(3):640-660.

Agnew, Julie R., Lisa R. Anderson, Jeffrey R. Gerlach, and Lisa R. Szykman, 2008. "Who Chooses Annuities? An Experimental Investigation of the Role of Gender, Framing, and Default." American Economic Review 98:418-442.

Aizer, Anna, 2010. "The Gender Wage Gap and Domestic Violence." American Economic Review100:1847-1859.

Akerlof, George, A., and Rachel E. Kranton, 2000. "Economics and Identity." Quarterly Journal of Economics 115:715-1753.

Alesina, Alberto, F., Francesca Lotti and Paolo, Mistrulli E., 2013. "Do Women Pay More for Credit? Evidence from Italy." Journal of the European Economic Association 11:45-66.

Altonji, Joseph G., Todd E. Elder, and Christopher R. Taber. 2005. "Selection on Observed and Unobserved Variables: Assessing the Effectiveness of Catholic school." Journal of Political Economy 113:151-184.

Bacolod Marigee and Bernardo Blum. 2010. "Two Sides of the Same Coins: US Residual Inequality and the Gender Gap." Journal of Human Resources 45(1): 197-242.

Barber, Brad, M., and Terrance Odean. 2001. "Boys Will Be Boys: Gender, Overconfidence, and Common Stock Investment.” Quarterly Journal of Economics 116: 261-292.

Bartling, Bjorn, Ernst Fehr, and Daniel Schunk. 2012. "Health Effects on Children's Willingness to Compete." Experimental Economics 15(1): 58-70.

Becker, Gary S. 1985. "Human Capital, Effort and the Sexual Division of Labor." Journal of Labor Economics 3(1): S33-S58.

Bertrand, Marianne and Kevin F. Hallock. 2001. "The Gender Gap in Top Corporate Jobs." Industrial and Labor Relations Review15: 3-21.

Bertrand, Marianne, Claudia Goldin, and Lawrence F. Katz. 2010. "Dynamics of the Gender Gap for Young Professionals in the Financial and Corporate Sectors." American Economic Journal: Applied Economics 2(3):228-55.

Bertrand, Marianne. 2011. "New Perspectives on Gender." Pp.1543-1590 in Handbook of Labor Economics, edited by O. Ashenfelter and D.Card. Amsterdam: Elsevier.

Bertrand, Marianne, Emir Kamenica, and Jessica Pan. 2015. "Gender Identity and Relative Income within Households.” Quarterly Journal of Economics 130(2):571-614.

Blau, Francine D. and Lawrence M. Kahn. 1997. "Swimming Upstream: Trends in the Gender Wage Differential in the 1980s." Journal of Labor Economics 15(1): 1-42.

Blau, Francine D. and Lawrence M. Kahn. 2006. "The US Gender Pay Gap in the 1990s: Slowing Convergence.” Industrial and Labor Relations Review 60(1): 45-66. 
Byrnes, James P., David C. Miller and William D. Schafer. 1999. "Gender Differences in Risk Taking: A Meta-Analysis." Psychological Bulletin 125(3): 367-383.

Croson, Rachel and Uri Gneezy. 2009. "Gender differences in Preferences." Journal of Economic Literature 47(2): 1-27.

Dohmen, Thomas, and Armin Falk. 2011. "Performance Pay and Multidimensional Sorting: Productivity, Preferences, and Gender." American Economic Review 101(2): 556-590.

Eckel, Catherine C., and Philip J. Grossman. 2008. "Men, Women and Risk Aversion: Experimental Evidence." Pp.1061-1073 in the Handbook of Experimental Economics Results, edited by Charles Plott and Vernon Smith. New York: Elsevier.

Gelman, Andrew, 2009. Red State, Blue State, Rich State and Poor State: Why American s vote the way they do Princeton University Press.

Gneezy, Uri, Kenneth L.Leonard and John A. List. 2009 "Gender Difference in Competition: Evidence from Matrilineal and Patriarchal Society.”Econometrica 77(5): 1637-1664.

Goldin, Claudia, 2014. "A Grand Gender Convergence: Its Last Chapter.” American Economic Review 104(4): 1091-1119.

Goldin, Claudia and Maria Shim, 2004 "Making a name: Women's surnames at marriage and beyond." Journal of Economic Perspectives 18(2): 143-160.

Goldin, Claudia, Lawrence F. Katz and Ilyana Kuziemko, 2006 "The Homecoming of American College Women: the Reversal of the College Gender Gap." Journal of Economic Perspectives 20(4): 133-156.

Guiso, Luigi, F. Monte, Paola Sapienza and Luigi Zigales, 2008. "Culture, Gender and Math." Science 30, 320.

Hoffman,M. U. Gneezy and J. A. List, 2011. "Nurture Affects Gender Differences in Spatial Abilities.” Proceedings of the National Academy of Sciences, 108(306):14786-14788.

Jepsen, Lisa, and Chirstopher Jepsen. 2002. "An Empirical Analysis of the Matching Patterns of same-sex and opposite-sex couples" Demography 39(3):435-453.

Jianakoplos, Nancy Ammon, and Alexandra Bernasek. 1998. “Are Women More Risk Averse?" Economic Inquiry 36(4):620-630.

Katz, Larry F, and Kevin M Murphy. 1992. "Changes in Relative Wages, 1963-1987: Supply and Demand Factors." Quarterly Journal of Economics 107:35-78.

Maestripieri, D., Paola Sapienza and Luigi Zingales, 2009. "Gender Difference in Financial Risk Aversion and Career Choices are Affected by Testosterone." Proceedings of the National Academy of Sciences, 124(3):1095-1131.

Muravyev, Alexander, Oleksandr Talavera and Dorothea Schafer. 2009. "Entrepreneurs' Gender and Financial Constraints: Evidence from International Data." Journal of Comparative Economics 37(2): 270-286. 
Niederle, Muriel, and Lise Vesterlund. 2007. "Do Women Shy Away from Competition? Do Men Compete Too Much?" Quarterly Journal of Economics 122(3): 1067-1101.

Niederle, Muriel, 2014. "Gender." Handbook of Experimental Economics, second edition, Eds. John Kagel and Alvin E. Roth, forthcoming.

Peterson, Richard L. 1981. “An Investigation of Sex Discrimination in Commercial Banks' Direct Consumer Lending.” Bell Journal of Economics 12(2): 547-561.

Pope, Devin G., and Justin R. Sydnor. 2010. "Geographic Variation in the Gender Differences in Test Scores." Journal of Economic Perspectives, 24(2): 95-108.

Schubert, Renate, Martin Brown, Matthias Gysler, and Hans Wolfgang Brachinger. 1999. "Financial Decision-Making: Are Women Really More Risk-Averse?" American Economic Review 89(2): 381-385.

Stannard,Una. 1977. Mrs. Man. San Francisco,California: Germainebooks.

Sunden, Annika E., and Brian J. Surette. 1998. "Gender Differences in the Allocation of Assets in Retirement Savings Plan.” American Economic Review 88(2): 207-211. 


\section{Table 1: Summary Statistics}

This table presents summary statistics for the data used in this paper from 2004 to 2014. Panel A reports the mean, standard deviation and critical percentile values of the mortgage and demographic variables for all borrowers in our sample. Panel B focus on the statistics of first signers within each couple for the full, different- and same-gender sample. Please refer to Appendix A for detailed definitions.

\begin{tabular}{|c|c|c|c|c|c|c|c|c|}
\hline & $\mathrm{N}$ & Mean & SD & $\min$ & p25 & $\mathrm{p} 50$ & p75 & $\max$ \\
\hline \multicolumn{9}{|c|}{ Panel A All Signers_Full sample } \\
\hline \multicolumn{9}{|l|}{ Demographics } \\
\hline Age & $1,339,322$ & 42 & 12 & 18 & 33 & 39 & 50 & 99 \\
\hline Auto Number & $1,339,322$ & 0.26 & 0.53 & 0 & 0 & 0 & 0 & 11 \\
\hline Education & $1,339,322$ & 0.80 & 0.40 & 0 & 1 & 1 & 1 & 1 \\
\hline FICO & $1,339,322$ & 760 & 50 & 377 & 733 & 773 & 796 & 844 \\
\hline Income & $1,338,951$ & 4,644 & 4,302 & - & 1,910 & 3,995 & 6,346 & 79,400 \\
\hline \multicolumn{9}{|c|}{ Relative variables Demographics } \\
\hline Higher Income Dummy & $1,339,322$ & 0.50 & 0.50 & 0 & 0 & 0 & 1 & 1 \\
\hline Older Age Dummy & $1,339,322$ & 0.30 & 0.46 & 0 & 0 & 0 & 1 & 1 \\
\hline More Autos Dummy & $1,339,322$ & 0.17 & 0.38 & 0 & 0 & 0 & 0 & 1 \\
\hline Higher FICO Dummy & $1,339,322$ & 0.22 & 0.42 & 0 & 0 & 0 & 0 & 1 \\
\hline Higher Education Dummy & $1,339,322$ & 0.19 & 0.40 & 0 & 0 & 0 & 0 & 1 \\
\hline Same Surname Dummy & $1,339,322$ & 0.89 & 0.32 & 0 & 1 & 1 & 1 & 1 \\
\hline
\end{tabular}




\begin{tabular}{lcccccc}
\hline & \multicolumn{2}{c}{ All } & \multicolumn{2}{c}{ Different Gender } & \multicolumn{2}{c}{ Same Gender } \\
& mean & SD & mean & SD & mean & SD \\
\hline Panel B First Signer (Same vs Different-gender group) & & & & & & \\
\hline Demographics & & & & & & \\
Age & 42.96 & 12.10 & 42.94 & 12.10 & 43.80 & 11.97 \\
Auto Number & 0.36 & 0.61 & 0.36 & 0.61 & 0.38 & 0.61 \\
College or Higher Dummy & 0.81 & 0.40 & 0.81 & 0.40 & 0.83 & 0.38 \\
FICO & 758.9 & 50.6 & 758.8 & 50.6 & 759.4 & 50.5 \\
Monthly Income & 6,511 & 4,593 & 6,509 & 4,594 & 6,587 & 4,530 \\
Same Surname Dummy & 0.89 & 0.31 & 0.89 & 0.31 & 0.70 & 0.46 \\
Men Signing First & 0.88 & 0.32 & 0.89 & 0.31 & 0.47 & 0.50 \\
Mortgage Characteristics & & & & & & \\
CLTV (\%) & 81.45 & 15.37 & 81.45 & 15.37 & 81.25 & 15.43 \\
Backend (\%) & 36.21 & 11.51 & 36.21 & 11.51 & 36.15 & 11.26 \\
Note Rate (\%) & 5.13 & 1.05 & 5.13 & 1.05 & 5.04 & 1.00 \\
Relative variables & & & & & & \\
Higher Income Dummy & 0.79 & 0.40 & 0.79 & 0.40 & 0.78 & 0.42 \\
Older Age Dummy & 0.44 & 0.50 & 0.44 & 0.50 & 0.42 & 0.49 \\
More Autos Dummy & 0.25 & 0.43 & 0.25 & 0.43 & 0.25 & 0.43 \\
Higher FICO Dummy & 0.20 & 0.40 & 0.20 & 0.40 & 0.22 & 0.41 \\
Higher Education Dummy & 0.23 & 0.42 & 0.23 & 0.42 & 0.24 & 0.42 \\
& & & & & & 11,971 \\
Counts & 672,595 & & 660,624 & &
\end{tabular}




\section{Table 2: Gender bias of signing order by age and income}

This table presents the distribution of male signing first among different income and age pairs conditional on genders. Panel A shows the statistics for six age categories (i) $<=25$, (ii) 26 to 35 , (iii) 36 to 45 , (iv) 46 to 55 , (v) 56 to 65 and (vi) $>65$. Panel B reports for nine income categories (i) $<=\$ 1 \mathrm{~K}$, (ii) $1 \mathrm{~K}$ to $2 \mathrm{~K}$, (iii) $2 \mathrm{~K}$ to $3 \mathrm{~K}$, (iv) $3 \mathrm{~K}$ to $4 \mathrm{~K}$, (v) $4 \mathrm{~K}$ to $5 \mathrm{~K}$, (vi) $5 \mathrm{~K}$ to $6 \mathrm{~K}$, (vii) $6 \mathrm{~K}$ to $7 \mathrm{~K}$, (viii) $7 \mathrm{~K}$ to $10 \mathrm{~K}$ and (ix) $>10 \mathrm{~K}$. The sample only includes differentgendered pair.

\begin{tabular}{|c|c|c|c|c|c|c|c|c|}
\hline \multicolumn{9}{|l|}{ Panel A Age } \\
\hline \multirow{8}{*}{$\begin{array}{l}\sum_{1}^{\infty} \\
-\infty \\
-\infty \\
\sum \\
\sum\end{array}$} & & \multicolumn{6}{|c|}{ Women's Age } & \multirow[b]{2}{*}{ Total } \\
\hline & & $<=25$ & $26-35$ & $36-45$ & $46-55$ & $56-65$ & $>65$ & \\
\hline & $<=25$ & $89 \%$ & $81 \%$ & $52 \%$ & $78 \%$ & $73 \%$ & $75 \%$ & $87 \%$ \\
\hline & $26-35$ & $91 \%$ & $88 \%$ & $84 \%$ & $77 \%$ & $68 \%$ & $76 \%$ & $88 \%$ \\
\hline & $36-45$ & $91 \%$ & $88 \%$ & $89 \%$ & $87 \%$ & $83 \%$ & $74 \%$ & $89 \%$ \\
\hline & $46-55$ & $81 \%$ & $89 \%$ & $89 \%$ & $90 \%$ & $90 \%$ & $87 \%$ & $90 \%$ \\
\hline & $56-65$ & $62 \%$ & $87 \%$ & $85 \%$ & $88 \%$ & $92 \%$ & $92 \%$ & $91 \%$ \\
\hline & $>65$ & $100 \%$ & $82 \%$ & $79 \%$ & $82 \%$ & $91 \%$ & $94 \%$ & $92 \%$ \\
\hline & Total & $91 \%$ & $88 \%$ & $89 \%$ & $89 \%$ & $92 \%$ & $94 \%$ & $89 \%$ \\
\hline
\end{tabular}

\begin{tabular}{|c|c|c|c|c|c|c|c|c|c|c|c|}
\hline \multicolumn{12}{|c|}{ Panel B Income } \\
\hline \multirow{11}{*}{ 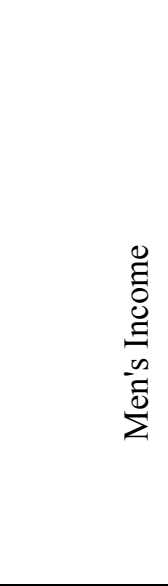 } & & \multicolumn{9}{|c|}{ Women's Income } & \multirow[b]{2}{*}{ Total } \\
\hline & & $<=\$ 1 \mathrm{~K}$ & $<=\$ 2 \mathrm{~K}$ & $<=\$ 3 \mathrm{~K}$ & $<=\$ 4 \mathrm{~K}$ & $<=\$ 5 \mathrm{~K}$ & $<=\$ 6 \mathrm{~K}$ & $<=\$ 7 \mathrm{~K}$ & $<=10 \mathrm{~K}$ & $>\$ 10 \mathrm{~K}$ & \\
\hline & $<=\$ 1 \mathrm{~K}$ & $92 \%$ & $70 \%$ & $62 \%$ & $57 \%$ & $50 \%$ & $46 \%$ & $42 \%$ & $38 \%$ & $35 \%$ & $46 \%$ \\
\hline & $<=\$ 2 \mathrm{~K}$ & $96 \%$ & $88 \%$ & $78 \%$ & $70 \%$ & $65 \%$ & $60 \%$ & $59 \%$ & $56 \%$ & $56 \%$ & $78 \%$ \\
\hline & $<=\$ 3 \mathrm{~K}$ & $97 \%$ & $94 \%$ & $86 \%$ & $76 \%$ & $69 \%$ & $66 \%$ & $61 \%$ & $58 \%$ & $54 \%$ & $83 \%$ \\
\hline & $<=\$ 4 \mathrm{~K}$ & $98 \%$ & $95 \%$ & $92 \%$ & $85 \%$ & $77 \%$ & $71 \%$ & $65 \%$ & $62 \%$ & $58 \%$ & $87 \%$ \\
\hline & $<=\$ 5 \mathrm{~K}$ & $98 \%$ & $96 \%$ & $95 \%$ & $91 \%$ & $85 \%$ & $78 \%$ & $73 \%$ & $65 \%$ & $61 \%$ & $90 \%$ \\
\hline & $<=\$ 6 \mathrm{~K}$ & $98 \%$ & $97 \%$ & $95 \%$ & $93 \%$ & $90 \%$ & $86 \%$ & $79 \%$ & $70 \%$ & $65 \%$ & $92 \%$ \\
\hline & $<=\$ 7 \mathrm{~K}$ & $99 \%$ & $97 \%$ & $96 \%$ & $95 \%$ & $92 \%$ & $89 \%$ & $84 \%$ & $76 \%$ & $67 \%$ & $94 \%$ \\
\hline & $<=10 \mathrm{~K}$ & $99 \%$ & $97 \%$ & $97 \%$ & $96 \%$ & $94 \%$ & $93 \%$ & $91 \%$ & $84 \%$ & $74 \%$ & $95 \%$ \\
\hline & $>\$ 10 \mathrm{~K}$ & $99 \%$ & $98 \%$ & $97 \%$ & $97 \%$ & $96 \%$ & $95 \%$ & $94 \%$ & $91 \%$ & $85 \%$ & $97 \%$ \\
\hline & Total & $98 \%$ & $95 \%$ & $91 \%$ & $87 \%$ & $83 \%$ & $80 \%$ & $76 \%$ & $71 \%$ & $62 \%$ & $89 \%$ \\
\hline
\end{tabular}




\section{Table 3: The role of income in being the first signer}

The table reports the OLS regression estimates of the husband earning more income on being the first signer. The sample includes all mortgages with different-gender applicants in the full sample. The dependent variable is equal to 1 if the husband is the first signer, and zero otherwise. Please refer to Appendix A for the definition of other variables. In Column 4, we include state and year fixed effects. Standard errors are clustered by state. Robust tstatistics are reported in brackets. $* * *, *$, and * correspond to statistical significance at $1 \%, 5 \%$ and $10 \%$ level respectively.

\begin{tabular}{|c|c|c|c|c|}
\hline \multicolumn{5}{|c|}{ Dependent Variable $=\mathrm{D}($ Man Signing First $)$} \\
\hline & (1) & (2) & (3) & (4) \\
\hline Higher Income Dummy_Men & $\begin{array}{c}0.262 * * * \\
(36.52)\end{array}$ & $\begin{array}{c}0.256 * * * \\
(36.86)\end{array}$ & $\begin{array}{c}0.200 * * * \\
(34.36)\end{array}$ & $\begin{array}{c}0.194 * * * \\
(35.72)\end{array}$ \\
\hline Older Age Dummy_Men & & $\begin{array}{l}0.001 \\
(1.13)\end{array}$ & $\begin{array}{l}-0.001 \\
(-0.91)\end{array}$ & $\begin{array}{l}-0.001 \\
(-1.85)\end{array}$ \\
\hline More Autos Dummy_Men & & $\begin{array}{c}0.032 * * * \\
(18.62)\end{array}$ & $\begin{array}{c}0.037 * * * \\
(17.56)\end{array}$ & $\begin{array}{c}0.036 * * * \\
(17.79)\end{array}$ \\
\hline Higher FICO Dummy_Men & & $\begin{array}{l}0.001 \\
(1.00)\end{array}$ & $\begin{array}{l}-0.001 \\
(-0.84)\end{array}$ & $\begin{array}{l}-0.002 \\
(-1.83)\end{array}$ \\
\hline Higher Education Dummy_Men & & $\begin{array}{c}0.026 * * * \\
(20.10)\end{array}$ & $\begin{array}{c}0.021 * * * \\
(16.82)\end{array}$ & $\begin{array}{c}0.016^{* * * *} \\
(17.31)\end{array}$ \\
\hline Age_Men & & & $\begin{array}{c}0.001 * * * \\
(8.68)\end{array}$ & $\begin{array}{c}0.001 * * * \\
(10.23)\end{array}$ \\
\hline Auto Number_Men & & & $\begin{array}{c}-0.008 * * * \\
(-5.33)\end{array}$ & $\begin{array}{c}-0.008 * * * \\
(-6.08)\end{array}$ \\
\hline Education_Men & & & $\begin{array}{c}-0.003^{*} \\
(-2.65)\end{array}$ & $\begin{array}{l}0.000 \\
(0.05)\end{array}$ \\
\hline Ln(FICO)_Men & & & $\begin{array}{c}0.208 * * * \\
(25.50)\end{array}$ & $\begin{array}{c}0.244 * * * \\
(32.07)\end{array}$ \\
\hline Ln(Income)_Men & & & $\begin{array}{c}0.022 * * * \\
(13.69)\end{array}$ & $\begin{array}{c}0.028 * * * \\
(22.20)\end{array}$ \\
\hline Constant & $\begin{array}{c}0.695 * * * \\
(83.43)\end{array}$ & $\begin{array}{c}0.686 * * * \\
(80.61)\end{array}$ & $\begin{array}{c}-0.846 * * * \\
(-13.85)\end{array}$ & $\begin{array}{c}-1.210 * * * \\
(-20.98)\end{array}$ \\
\hline State FE & $\mathrm{N}$ & $\mathrm{N}$ & $\mathrm{N}$ & $\mathrm{Y}$ \\
\hline Year FE & $\mathrm{N}$ & $\mathrm{N}$ & $\mathrm{N}$ & $\mathrm{Y}$ \\
\hline Observations & 652452 & 652452 & 631280 & 631280 \\
\hline Adjusted R-squared & 0.133 & 0.136 & 0.109 & 0.116 \\
\hline
\end{tabular}




\section{Table 4: Comparing loans with male and female as the first signer}

This table reports the summary statistics of demographic and mortgage variables for loans first signed by male and female. The sample includes all mortgages with different-gender applicants in the full sample. Please refer to Appendix A for definitions. ***, **, and * correspond to statistical significance (of difference in means tests, in column (5)) at $1 \%, 5 \%$ and $10 \%$ level respectively.

\begin{tabular}{|c|c|c|c|c|c|}
\hline & \multicolumn{2}{|c|}{ Male first signer } & \multicolumn{2}{|c|}{ Female first signer } & \multirow{2}{*}{ Difference } \\
\hline & mean & $\mathrm{Sd}$ & mean & sd & \\
\hline \multicolumn{6}{|l|}{ Demographics } \\
\hline Higher Income Dummy & 0.70 & 0.46 & 0.81 & 0.39 & -0.11 \\
\hline Older Age Dummy & 0.18 & 0.38 & 0.48 & 0.50 & -0.30 \\
\hline More Autos Dummy & 0.19 & 0.39 & 0.26 & 0.44 & -0.07 \\
\hline Higher FICO Dummy & 0.28 & 0.45 & 0.20 & 0.40 & 0.08 \\
\hline Higher Education Dummy & 0.30 & 0.46 & 0.22 & 0.41 & 0.08 \\
\hline Age & 40.35 & 10.81 & 43.30 & 12.22 & -2.95 \\
\hline Auto Number & 0.29 & 0.53 & 0.37 & 0.62 & -0.07 \\
\hline Education & 0.85 & 0.36 & 0.80 & 0.40 & 0.05 \\
\hline FICO & 756.0 & 51.7 & 759.2 & 50.5 & -3.22 \\
\hline Income & 5,815 & 3,951 & 6,603 & 4,663 & -788 \\
\hline Same Surname Dummy & 0.80 & 0.40 & 0.90 & 0.30 & -0.10 \\
\hline \multicolumn{6}{|l|}{ Mortgage Characteristics } \\
\hline CLTV $(\%)$ & 83.1 & 14.4 & 81.2 & 15.5 & 1.85 \\
\hline Backend $(\%)$ & 36.3 & 11.2 & 36.2 & 11.5 & 0.11 \\
\hline Note Rate $(\%)$ & 5.1 & 1.1 & 5.1 & 1.1 & 0.00 \\
\hline $\mathrm{N}$ & \multicolumn{2}{|c|}{588,533} & \multicolumn{2}{|c|}{72,091} & \\
\hline
\end{tabular}




\section{Table 5: Relative Income Hypothesis and Loan officer bias}

The table reports results whether the relative economic power hypothesis is driven by the bias of loan officer. The sample includes all mortgages with different-gender applicants in the full sample. The dependent variable is equal to 1 if the husband is the first signer, and zero otherwise. We define a loan officer to be biased if all loans extended by him/her are always first signed by the male. Loan office fixed effect is included in Column 1 while in Column 2 and 3, the sample is divided by the type of loan officers. Standard errors are clustered by state. Please refer to Appendix A for the definition of other variables. Robust t-statistics are reported in brackets. ***, **, and * correspond to statistical significance at $1 \%, 5 \%$ and $10 \%$ level respectively.

\begin{tabular}{|c|c|c|c|}
\hline \multicolumn{4}{|c|}{ Dependent Variable $=D($ Man Signing First $)$} \\
\hline & (1) & (2) & (3) \\
\hline & Full & Biased Loan Officer & Non-biased Loan Officer \\
\hline \multirow[t]{2}{*}{ Higher Income Dummy_Men } & $0.193 * * *$ & $0.191 * * *$ & $0.237 * * *$ \\
\hline & $(35.75)$ & $(35.56)$ & $(19.51)$ \\
\hline \multirow[t]{2}{*}{ Older Age Dummy_Men } & -0.001 & -0.001 & -0.004 \\
\hline & $(-1.75)$ & $(-1.52)$ & $(-1.09)$ \\
\hline \multirow[t]{2}{*}{ More Autos Dummy_Men } & $0.036^{* * *}$ & $0.034 * * *$ & $0.066 * * *$ \\
\hline & $(17.50)$ & $(16.69)$ & $(8.55)$ \\
\hline \multirow[t]{2}{*}{ Higher FICO Dummy_Men } & -0.002 & -0.002 & 0.000 \\
\hline & $(-1.84)$ & $(-1.95)$ & $(0.03)$ \\
\hline \multirow[t]{2}{*}{ Higher Education Dummy_Men } & $0.016^{* * *}$ & $0.016^{* * *}$ & $0.022 * * *$ \\
\hline & $(17.82)$ & $(16.83)$ & (7.97) \\
\hline \multirow[t]{2}{*}{ Age_Men } & $0.001 * * *$ & $0.001 * * *$ & $0.001 * * *$ \\
\hline & $(10.88)$ & $(9.90)$ & $(5.70)$ \\
\hline \multirow[t]{2}{*}{ Auto Number_Men } & $-0.008 * * *$ & $-0.008 * * *$ & $-0.022 * * *$ \\
\hline & $(-6.23)$ & $(-5.88)$ & $(-3.92)$ \\
\hline \multirow[t]{2}{*}{ Education_Men } & 0.000 & 0.000 & 0.014 \\
\hline & $(0.41)$ & $(0.25)$ & $(1.63)$ \\
\hline \multirow[t]{2}{*}{ Ln(FICO)_Men } & $0.245^{* * *}$ & $0.244 * * *$ & $0.302 * * *$ \\
\hline & $(32.28)$ & $(32.06)$ & $(6.97)$ \\
\hline \multirow[t]{2}{*}{ Ln(Income)_Men } & $0.029 * * *$ & $0.028 * * *$ & $0.067 * * *$ \\
\hline & $(23.09)$ & $(23.21)$ & $(13.91)$ \\
\hline \multirow[t]{2}{*}{ Constant } & $-1.196 * * *$ & $-1.170 * * *$ & $-1.806 * * *$ \\
\hline & $(-20.82)$ & $(-20.70)$ & $(-6.41)$ \\
\hline State FE & $\mathrm{Y}$ & $\mathrm{Y}$ & $\mathrm{Y}$ \\
\hline Year FE & $\mathrm{Y}$ & $\mathrm{Y}$ & $\mathrm{Y}$ \\
\hline Loan Officer FE & $\mathrm{Y}$ & $\mathrm{Y}$ & $\mathrm{Y}$ \\
\hline Observations & 631280 & 604562 & 26718 \\
\hline Adjusted R-squared & 0.120 & 0.115 & 0.159 \\
\hline
\end{tabular}




\section{Table 6: The importance of socio cultural variable-surname retention}

The table examines whether the relative income hypothesis is a reflection of the socio culture effect. The sample includes all mortgages with different-gender applicants in the full sample. The dependent variable is equal to 1 if the husband is the first signer, and zero otherwise. We compare the last names of the applicants and define the variable same surnames to be one if they are the same and zero otherwise. Same Surnames is included in Column 1 while in Column 2 and 3, the sample is divided by whether the surname are the same for both applicants. State, year and loan office fixed effect are included in all specifications. Standard errors are clustered by state. Please refer to Appendix A for the definition of other variables. Robust $\mathrm{t}$-statistics are reported in brackets. ***, **, and * correspond to statistical significance at $1 \%, 5 \%$ and $10 \%$ level respectively.

\begin{tabular}{|c|c|c|c|}
\hline \multicolumn{4}{|c|}{ Dependent Variable $=\mathrm{D}($ Man Signing First $)$} \\
\hline & (1) & (2) & (3) \\
\hline & & Same surname & Different surname \\
\hline \multirow[t]{2}{*}{ Higher Income Dummy_Men } & $0.190 * * *$ & $0.184 * * *$ & $0.230 * * *$ \\
\hline & $(35.72)$ & (34.89) & $(27.06)$ \\
\hline \multirow[t]{2}{*}{ Older Age Dummy_Men } & -0.001 & $-0.002 * * *$ & $0.013 * * *$ \\
\hline & $(-0.75)$ & $(-3.81)$ & $(4.13)$ \\
\hline \multirow[t]{2}{*}{ More Autos Dummy_Men } & $0.034 * * *$ & $0.032 * * *$ & $0.048 * * *$ \\
\hline & $(17.33)$ & $(15.20)$ & $(7.63)$ \\
\hline \multirow[t]{2}{*}{ Higher FICO Dummy_Men } & -0.000 & -0.002 & 0.007 \\
\hline & $(-0.25)$ & $(-1.68)$ & $(1.96)$ \\
\hline \multirow[t]{2}{*}{ Higher Education Dummy_Men } & $0.015^{* * *}$ & $0.014 * * *$ & $0.022 * * *$ \\
\hline & $(16.82)$ & $(17.66)$ & $(6.32)$ \\
\hline \multirow[t]{2}{*}{ Age_Men } & $0.001 * * *$ & $0.001 * * *$ & 0.000 \\
\hline & $(10.49)$ & $(11.55)$ & $(0.08)$ \\
\hline \multirow[t]{2}{*}{ Auto Number_Men } & $-0.008 * * *$ & $-0.007 * * *$ & $-0.012 * *$ \\
\hline & $(-5.91)$ & $(-4.53)$ & $(-2.89)$ \\
\hline \multirow[t]{2}{*}{ Education_Men } & 0.002 & 0.002 & 0.005 \\
\hline & $(1.58)$ & $(1.37)$ & $(1.29)$ \\
\hline \multirow[t]{2}{*}{ Ln(FICO)_Men } & $0.240 * * *$ & $0.230 * * *$ & $0.324 * * *$ \\
\hline & $(33.52)$ & $(29.80)$ & $(10.41)$ \\
\hline \multirow[t]{2}{*}{ Ln(Income)_Men } & $0.030 * * *$ & $0.029 * * *$ & $0.045 * * *$ \\
\hline & (23.19) & $(25.15)$ & $(8.27)$ \\
\hline \multirow[t]{2}{*}{ Same Surnames } & $0.058 * * *$ & & \\
\hline & (13.54) & & \\
\hline \multirow{2}{*}{ Constant } & $-1.217 * * *$ & $-1.065^{* * *}$ & $-1.959 * * *$ \\
\hline & $(-21.90)$ & $(-19.10)$ & $(-8.65)$ \\
\hline State FE & $\mathrm{Y}$ & $\mathrm{Y}$ & $\mathrm{Y}$ \\
\hline Year FE & $\mathrm{Y}$ & $\mathrm{Y}$ & $\mathrm{Y}$ \\
\hline Loan Officer FE & $\mathrm{Y}$ & $\mathrm{Y}$ & $\mathrm{Y}$ \\
\hline Observations & 631280 & 563478 & 67802 \\
\hline Adjusted R-squared & 0.123 & 0.116 & 0.130 \\
\hline
\end{tabular}




\section{Table 7: Gay couples}

The table presents the OLS regression estimates of the relative income on being the first signer. The unit of observation is the borrower instead of borrower pairs. Panel A and B reports the result for male-male and femalefemale pairs while Panel $\mathrm{C}$ is for the different-gender sample. The dependent variable is equal to 1 if the borrower is the first signer, and zero otherwise. Please refer to Appendix A for the definition of other variables. In Column 5, we include state, year and loan officer fixed effects. Standard errors are clustered by state. Robust t-statistics are reported in brackets. ${ }^{* *},{ }^{*}$, and $*$ correspond to statistical significance at $1 \%, 5 \%$ and $10 \%$ level respectively.

\begin{tabular}{|c|c|c|c|c|c|}
\hline \multicolumn{6}{|l|}{ Panel A Male-male pairs } \\
\hline \multicolumn{6}{|c|}{ Male-male pairs, Dependent Variable $=\mathrm{D}($ Signing first $)$} \\
\hline & $(1)$ & (2) & (3) & (4) & $(5)$ \\
\hline Higher Income Dummy & $\begin{array}{l}0.581 \text { *** } \\
(53.35)\end{array}$ & $\begin{array}{l}0.534 * * * \\
(45.57)\end{array}$ & $\begin{array}{l}0.410 * * * \\
(31.46)\end{array}$ & $\begin{array}{l}0.402 * * * \\
(30.23)\end{array}$ & $\begin{array}{l}0.398 * * * \\
(29.42)\end{array}$ \\
\hline Older Age Dummy & & $\begin{array}{l}0.150 * * * \\
(12.80)\end{array}$ & $\begin{array}{l}0.139 * * * \\
(11.47)\end{array}$ & $\begin{array}{l}0.138 * * * \\
(11.33)\end{array}$ & $\begin{array}{l}0.140^{* * *} \\
(11.50)\end{array}$ \\
\hline More Autos Dummy & & $\begin{array}{l}0.125^{* * *} \\
(13.79)\end{array}$ & $\begin{array}{l}0.123 * * * \\
(10.11)\end{array}$ & $\begin{array}{l}0.123^{* * *} \\
(10.22)\end{array}$ & $\begin{array}{l}0.116^{* * *} \\
(9.18)\end{array}$ \\
\hline Higher FICO Dummy & & $\begin{array}{l}-0.011 \\
(-1.20)\end{array}$ & $\begin{array}{l}-0.008 \\
(-0.77)\end{array}$ & $\begin{array}{l}-0.010 \\
(-0.98)\end{array}$ & $\begin{array}{l}-0.006 \\
(-0.64)\end{array}$ \\
\hline Higher Education Dummy & & $\begin{array}{l}0.029 * * \\
(3.26)\end{array}$ & $\begin{array}{l}0.025 * * \\
(2.77)\end{array}$ & $\begin{array}{l}0.020^{*} \\
(2.18)\end{array}$ & $\begin{array}{l}0.019^{*} \\
(2.14)\end{array}$ \\
\hline Age & & & $\begin{array}{l}0.001 * * * \\
(5.00)\end{array}$ & $\begin{array}{l}0.001 * * * \\
(5.45)\end{array}$ & $\begin{array}{l}0.001 * * * \\
(5.69)\end{array}$ \\
\hline Auto Number & & & $\begin{array}{l}-0.013 \\
(-1.68)\end{array}$ & $\begin{array}{l}-0.012 \\
(-1.57)\end{array}$ & $\begin{array}{l}-0.007 \\
(-0.84)\end{array}$ \\
\hline Education & & & $\begin{array}{l}-0.025 * * * \\
(-4.07)\end{array}$ & $\begin{array}{l}-0.021 * * \\
(-3.47)\end{array}$ & $\begin{array}{l}-0.018 * * \\
(-2.97)\end{array}$ \\
\hline $\mathrm{Ln}(\mathrm{FICO})$ & & & $\begin{array}{l}0.099^{* *} \\
(3.00)\end{array}$ & $\begin{array}{l}0.156^{* * * *} \\
(4.16)\end{array}$ & $\begin{array}{l}0.147 * * * \\
(3.89)\end{array}$ \\
\hline Ln(Income) & & & $\begin{array}{l}0.093 * * * \\
(19.79)\end{array}$ & $\begin{array}{l}0.102 * * * \\
(20.26)\end{array}$ & $\begin{array}{l}0.106^{* * *} \\
(21.19)\end{array}$ \\
\hline Same Surnames & & & & & $\begin{array}{l}0.043 * * * \\
(12.22)\end{array}$ \\
\hline Constant & $\begin{array}{l}0.213^{* * *} \\
(41.20)\end{array}$ & $\begin{array}{l}0.163 * * * \\
(25.36)\end{array}$ & $\begin{array}{l}-1.182 * * * \\
(-5.35)\end{array}$ & $\begin{array}{l}-1.574 * * * \\
(-6.27)\end{array}$ & $\begin{array}{l}-1.581^{* * *} \\
(-6.35)\end{array}$ \\
\hline State FE & $\mathrm{N}$ & $\mathrm{N}$ & $\mathrm{N}$ & $\mathrm{Y}$ & $\mathrm{Y}$ \\
\hline Year FE & $\mathrm{N}$ & $\mathrm{N}$ & $\mathrm{N}$ & $\mathrm{Y}$ & $\mathrm{Y}$ \\
\hline Loan Officer FE & $\mathrm{N}$ & $\mathrm{N}$ & $\mathrm{N}$ & $\mathrm{N}$ & $\mathrm{Y}$ \\
\hline Observations & 10990 & 10990 & 10986 & 10986 & 10986 \\
\hline Adjusted R-squared & 0.338 & 0.367 & 0.379 & 0.377 & 0.377 \\
\hline
\end{tabular}




\begin{tabular}{|c|c|c|c|c|c|}
\hline \multicolumn{6}{|l|}{ Panel B Female-female pairs } \\
\hline \multicolumn{6}{|c|}{ Female-female pairs, Dependent Variable $=\mathrm{D}($ Signing first $)$} \\
\hline & (1) & $(2)$ & (3) & (4) & (5) \\
\hline Higher Income Dummy & $\begin{array}{l}0.540 * * * \\
(31.96)\end{array}$ & $\begin{array}{l}0.509 * * * \\
(29.15)\end{array}$ & $\begin{array}{l}0.398 * * * \\
(22.37)\end{array}$ & $\begin{array}{l}0.391 * * * \\
(21.69)\end{array}$ & $\begin{array}{l}0.388 * * * \\
(21.60)\end{array}$ \\
\hline Older Age Dummy & & $\begin{array}{l}0.123 * * * \\
(9.10)\end{array}$ & $\begin{array}{l}0.116^{* * *} \\
(8.00)\end{array}$ & $\begin{array}{l}0.116^{* * *} \\
(7.93)\end{array}$ & $\begin{array}{l}0.117 * * * \\
(7.98)\end{array}$ \\
\hline More Autos Dummy & & $\begin{array}{l}0.102 * * * \\
(9.86)\end{array}$ & $\begin{array}{l}0.073 * * * \\
(5.72)\end{array}$ & $\begin{array}{l}0.072 * * * \\
(5.75)\end{array}$ & $\begin{array}{l}0.068 * * * \\
(5.50)\end{array}$ \\
\hline Higher FICO Dummy & & $\begin{array}{l}-0.012 \\
(-1.09)\end{array}$ & $\begin{array}{l}-0.010 \\
(-0.86)\end{array}$ & $\begin{array}{l}-0.012 \\
(-0.97)\end{array}$ & $\begin{array}{l}-0.009 \\
(-0.76)\end{array}$ \\
\hline Higher Education Dummy & & $\begin{array}{l}0.035^{*} \\
(2.38)\end{array}$ & $\begin{array}{l}0.031^{*} \\
(2.09)\end{array}$ & $\begin{array}{l}0.027 \\
(1.80)\end{array}$ & $\begin{array}{l}0.026 \\
(1.74)\end{array}$ \\
\hline Age & & & $\begin{array}{l}0.001 * * * \\
(4.08)\end{array}$ & $\begin{array}{l}0.001 * * * \\
(4.42)\end{array}$ & $\begin{array}{l}0.001 * * * \\
(4.98)\end{array}$ \\
\hline Auto Number & & & $\begin{array}{l}0.014^{*} \\
(2.37)\end{array}$ & $\begin{array}{l}0.015^{* *} \\
(2.84)\end{array}$ & $\begin{array}{l}0.019 * * * \\
(3.89)\end{array}$ \\
\hline Education & & & $\begin{array}{l}-0.025 * * \\
(-3.33)\end{array}$ & $\begin{array}{l}-0.022 * * \\
(-2.79)\end{array}$ & $\begin{array}{l}-0.018^{*} \\
(-2.43)\end{array}$ \\
\hline $\operatorname{Ln}(\mathrm{FICO})$ & & & $\begin{array}{l}0.132 * * \\
(3.41)\end{array}$ & $\begin{array}{l}0.172 * * * \\
(4.13)\end{array}$ & $\begin{array}{l}0.171 * * * \\
(4.19)\end{array}$ \\
\hline Ln(Income) & & & $\begin{array}{l}0.094 * * * \\
(18.02)\end{array}$ & $\begin{array}{l}0.103 * * * \\
(18.36)\end{array}$ & $\begin{array}{l}0.104 * * * \\
(18.82)\end{array}$ \\
\hline Same Surnames & & & & & $\begin{array}{l}0.034 * * * \\
(8.18)\end{array}$ \\
\hline Constant & $\begin{array}{l}0.213 * * * \\
(41.20)\end{array}$ & $\begin{array}{l}0.163 * * * \\
(25.36)\end{array}$ & $\begin{array}{l}-1.182 * * * \\
(-5.35)\end{array}$ & $\begin{array}{l}-1.574 * * * \\
(-6.27)\end{array}$ & $\begin{array}{l}-1.581 * * * \\
(-6.35)\end{array}$ \\
\hline State FE & $\mathrm{N}$ & $\mathrm{N}$ & $\mathrm{N}$ & $\mathrm{Y}$ & $\mathrm{Y}$ \\
\hline Year FE & $\mathrm{N}$ & $\mathrm{N}$ & $\mathrm{N}$ & $\mathrm{Y}$ & $\mathrm{Y}$ \\
\hline Loan Officer FE & $\mathrm{N}$ & $\mathrm{N}$ & $\mathrm{N}$ & $\mathrm{N}$ & $\mathrm{Y}$ \\
\hline Observations & 12352 & 12352 & 10730 & 10730 & 10730 \\
\hline Adjusted R-squared & 0.292 & 0.312 & 0.267 & 0.265 & 0.266 \\
\hline
\end{tabular}




\begin{tabular}{|c|c|c|c|c|c|}
\hline \multicolumn{6}{|c|}{ Panel C Different-gender pairs } \\
\hline \multicolumn{6}{|c|}{ Male-female pairs, Dependent Variable $=\mathrm{D}$ (Signing first $)$} \\
\hline & $(1)$ & $(2)$ & $(3)$ & $(4)$ & $(5)$ \\
\hline \multirow[t]{2}{*}{ Higher Income Dummy } & $0.595^{* * *}$ & $0.540 * * *$ & $0.402 * * *$ & $0.394 * * *$ & $0.393^{* * *}$ \\
\hline & $(87.92)$ & $(89.06)$ & $(84.80)$ & $(83.49)$ & $(83.27)$ \\
\hline \multirow[t]{2}{*}{ Older Age Dummy } & & $0.205^{* * *}$ & $0.201 * * *$ & $0.200 * * *$ & $0.200 * * *$ \\
\hline & & $(43.03)$ & $(41.35)$ & $(41.23)$ & $(41.21)$ \\
\hline \multirow[t]{2}{*}{ More Autos Dummy } & & $0.125 * * *$ & $0.104 * * *$ & $0.103 * * *$ & $0.102 * * *$ \\
\hline & & $(46.89)$ & $(43.23)$ & $(42.30)$ & $(41.89)$ \\
\hline \multirow[t]{2}{*}{ Higher FICO Dummy } & & $-0.017 * * *$ & $-0.015^{* * *}$ & $-0.016 * * *$ & $-0.015^{* * *}$ \\
\hline & & $(-13.62)$ & $(-9.96)$ & $(-11.09)$ & $(-10.60)$ \\
\hline \multirow[t]{2}{*}{ Higher Education Dummy } & & -0.005 & $-0.017 * * *$ & $-0.021 * * *$ & $-0.022 * * *$ \\
\hline & & $(-1.19)$ & $(-3.75)$ & $(-4.75)$ & $(-4.85)$ \\
\hline \multirow[t]{2}{*}{ Age } & & & $0.001 * * *$ & $0.001 * * *$ & $0.001 * * *$ \\
\hline & & & $(10.46)$ & (14.48) & (14.94) \\
\hline \multirow[t]{2}{*}{ Auto\# } & & & -0.002 & -0.001 & -0.000 \\
\hline & & & $(-1.07)$ & $(-0.33)$ & $(-0.03)$ \\
\hline \multirow[t]{2}{*}{ College or Higher Dummy } & & & $-0.026 * * *$ & $-0.023 * * *$ & $-0.022 * * *$ \\
\hline & & & $(-18.22)$ & $(-15.58)$ & $(-15.47)$ \\
\hline \multirow[t]{2}{*}{$\operatorname{Ln}(\mathrm{FICO})$} & & & $0.068 * * *$ & $0.116^{* * *}$ & $0.114 * * *$ \\
\hline & & & $(7.25)$ & $(15.32)$ & $(15.03)$ \\
\hline \multirow[t]{2}{*}{$\operatorname{Ln}($ Income $)$} & & & $0.100 * * *$ & $0.109 * * *$ & $0.109 * * *$ \\
\hline & & & $(55.42)$ & $(75.80)$ & $(76.05)$ \\
\hline \multirow[t]{2}{*}{ Same Surnames } & & & & & $0.030 * * *$ \\
\hline & & & & & $(27.01)$ \\
\hline \multirow[t]{2}{*}{ Constant } & $0.206 * * *$ & $0.154 * * *$ & $-1.026 * * *$ & $-1.413 * * *$ & $-1.431 * * *$ \\
\hline & $(61.53)$ & $(45.30)$ & $(-15.13)$ & $(-26.75)$ & $(-27.32)$ \\
\hline State FE & $\mathrm{N}$ & $\mathrm{N}$ & $\mathrm{N}$ & $\mathrm{Y}$ & $\mathrm{Y}$ \\
\hline Year FE & $\mathrm{N}$ & $\mathrm{N}$ & $\mathrm{N}$ & $\mathrm{Y}$ & $\mathrm{Y}$ \\
\hline Loan Officer FE & $\mathrm{N}$ & $\mathrm{N}$ & $\mathrm{N}$ & $\mathrm{N}$ & $\mathrm{Y}$ \\
\hline Observations & 1302812 & 1302812 & 1084786 & 1084786 & 1084786 \\
\hline Adjusted R-squared & 0.354 & 0.399 & 0.330 & 0.332 & 0.332 \\
\hline
\end{tabular}




\section{Table 8: Falsification test - randomly assigning gender and higher income}

The table reports the falsification test for our main analysis. The sample includes all mortgages with different-gender applicants in the full sample. The dependent variable is equal to 1 if the husband is the first signer, and zero otherwise. In Column 1 we randomly assign gender to applicants while in column 2 the higher income in each pair is randomly assigned. Please refer to Appendix A for the definition of other variables. In all specifications, we include state, year and loan officer fixed effects. Standard errors are clustered by states. Robust t-statistics are reported in brackets. $* * *, * *$, and $*$ correspond to statistical significance at $1 \%, 5 \%$ and $10 \%$ level respectively.

\begin{tabular}{|c|c|c|}
\hline \multicolumn{3}{|c|}{ Dependent Variable $=\mathrm{D}($ Man Signing First $)$} \\
\hline & (1) & (2) \\
\hline \multirow[t]{2}{*}{ Higher Income Dummy_Men } & -0.001 & 0.000 \\
\hline & $(-0.78)$ & $(0.51)$ \\
\hline \multirow[t]{2}{*}{ Older Age Dummy_Men } & -0.001 & -0.000 \\
\hline & $(-1.22)$ & $(-0.33)$ \\
\hline \multirow[t]{2}{*}{ More Autos Dummy_Men } & 0.000 & $0.049 * * *$ \\
\hline & $(0.18)$ & (22.04) \\
\hline \multirow[t]{2}{*}{ Higher FICO Dummy_Men } & 0.002 & $-0.004 * * *$ \\
\hline & $(1.79)$ & $(-4.21)$ \\
\hline \multirow[t]{2}{*}{ Higher Education Dummy_Men } & -0.001 & $0.030 * * *$ \\
\hline & $(-0.91)$ & $(27.16)$ \\
\hline \multirow[t]{2}{*}{ Age_Men } & 0.000 & $0.001 * * *$ \\
\hline & $(1.04)$ & (11.55) \\
\hline \multirow[t]{2}{*}{ Auto Number_Men } & -0.000 & $-0.018 * * *$ \\
\hline & $(-0.21)$ & $(-12.26)$ \\
\hline \multirow[t]{2}{*}{ Education_Men } & 0.000 & $-0.015 * * *$ \\
\hline & $(0.00)$ & $(-10.80)$ \\
\hline \multirow[t]{2}{*}{ Ln(FICO)_Men } & -0.004 & $0.243 * * *$ \\
\hline & $(-0.66)$ & (33.68) \\
\hline \multirow[t]{2}{*}{ Ln(Income)_Men } & 0.001 & $0.093 * * *$ \\
\hline & $(0.92)$ & (31.98) \\
\hline \multirow[t]{2}{*}{ Same Surnames } & 0.001 & $0.073 * * *$ \\
\hline & $(0.71)$ & $(15.23)$ \\
\hline \multirow[t]{2}{*}{ Constant } & $0.927 * * *$ & $-1.623 * * *$ \\
\hline & $(22.82)$ & $(-24.88)$ \\
\hline State FE & Y & $\mathrm{Y}$ \\
\hline Year FE & $\mathrm{Y}$ & $\mathrm{Y}$ \\
\hline Loan Officer FE & $\mathrm{Y}$ & $\mathrm{Y}$ \\
\hline Observations & 631280 & 631280 \\
\hline Adjusted R-squared & -0.000 & 0.066 \\
\hline
\end{tabular}




\section{Figure 1 Distribution of income by Gender when man/women signs first}

This figure shows the distribution of income by gender for loans with male (Panel A) or female (Panel B) as the first signer.

Panel A Loans with male as first signer

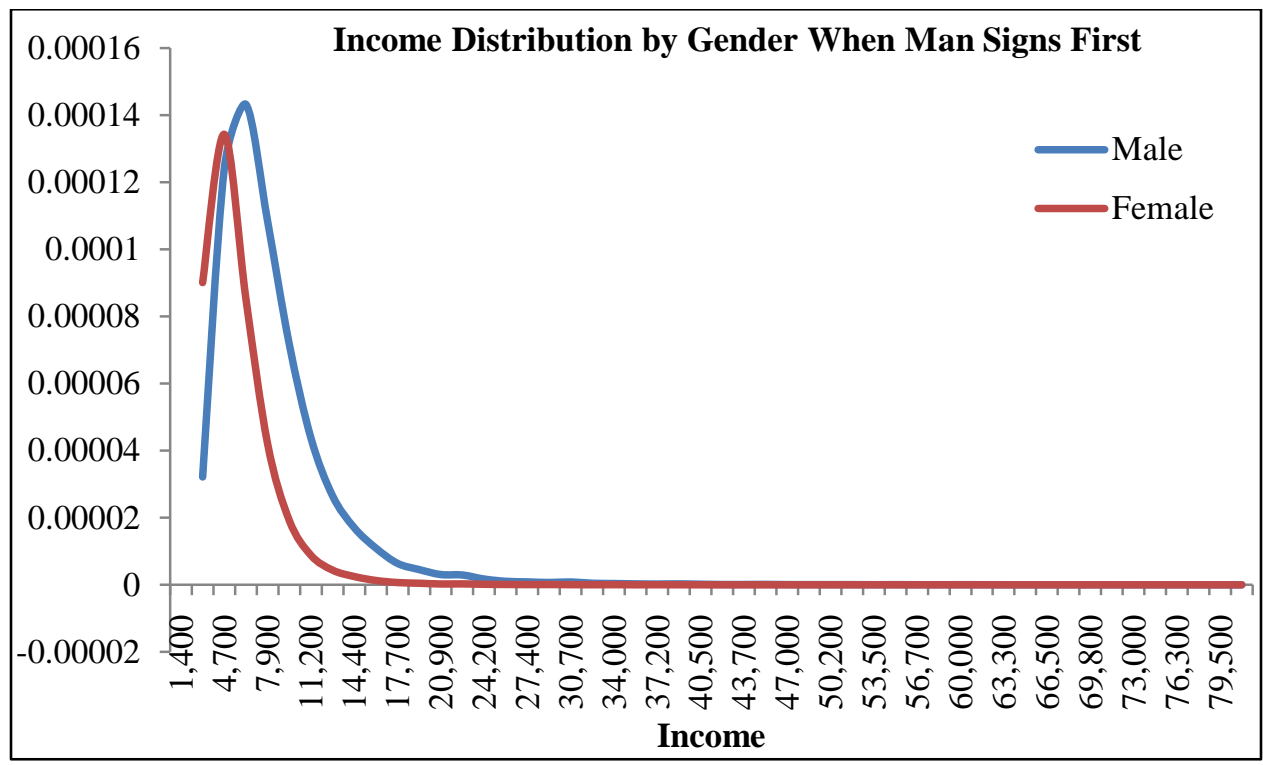

Panel B Loans with female as first signer

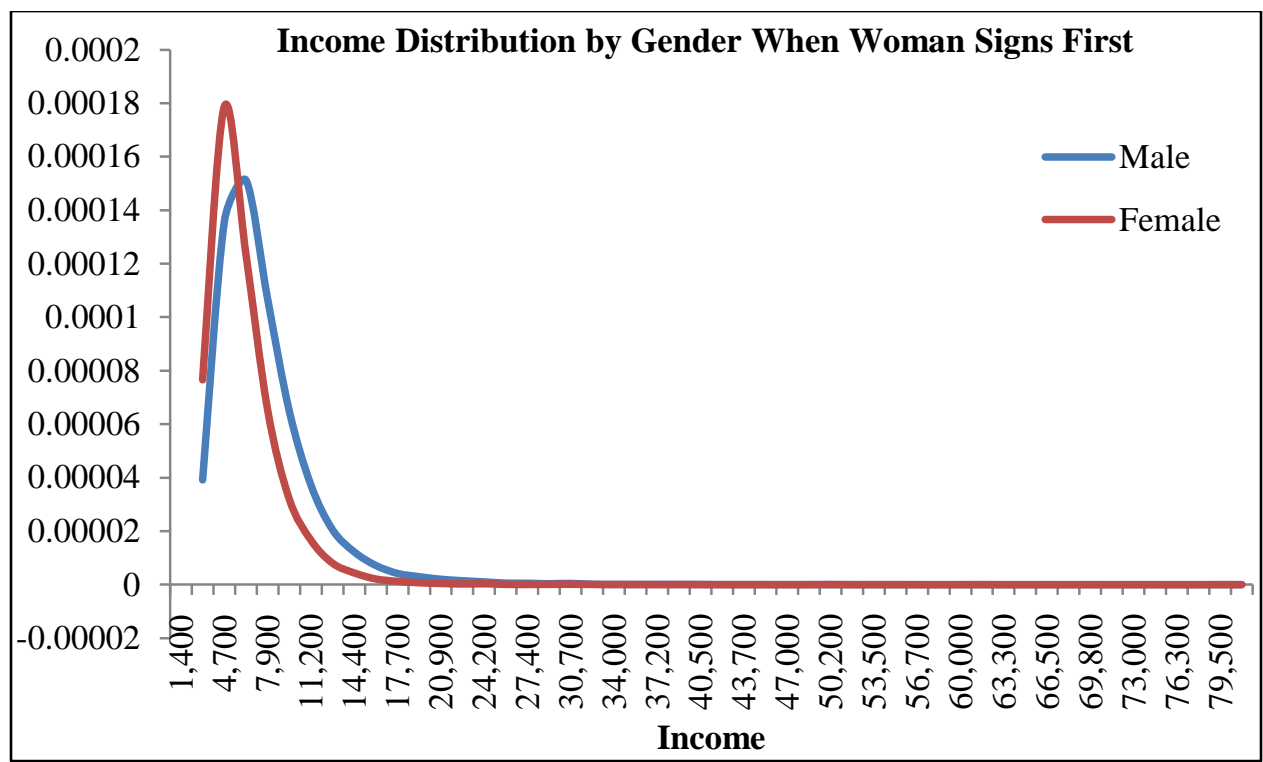




\section{Figure 2 Distribution of FICO by Gender when man/women signs first}

This figure shows the distribution of FICO by gender for loans with male (Panel A) or female (Panel B) as the first signer.

Panel A Loans with male as first signer

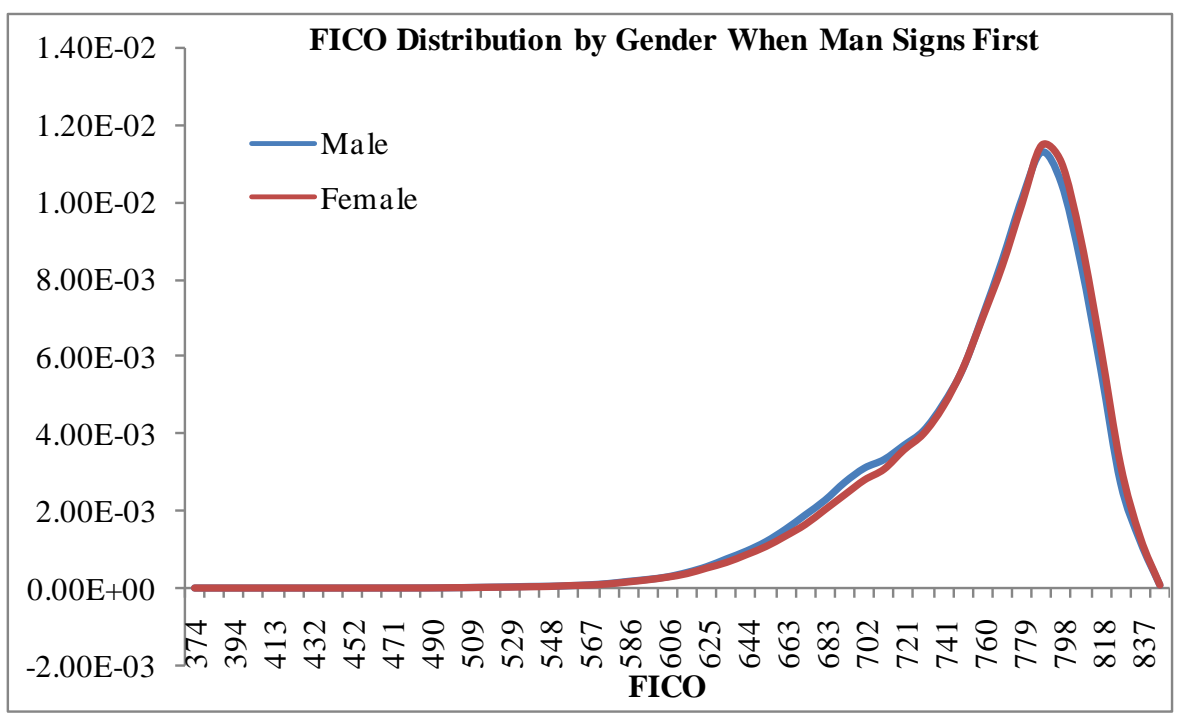

Panel B Loans with female as first signer

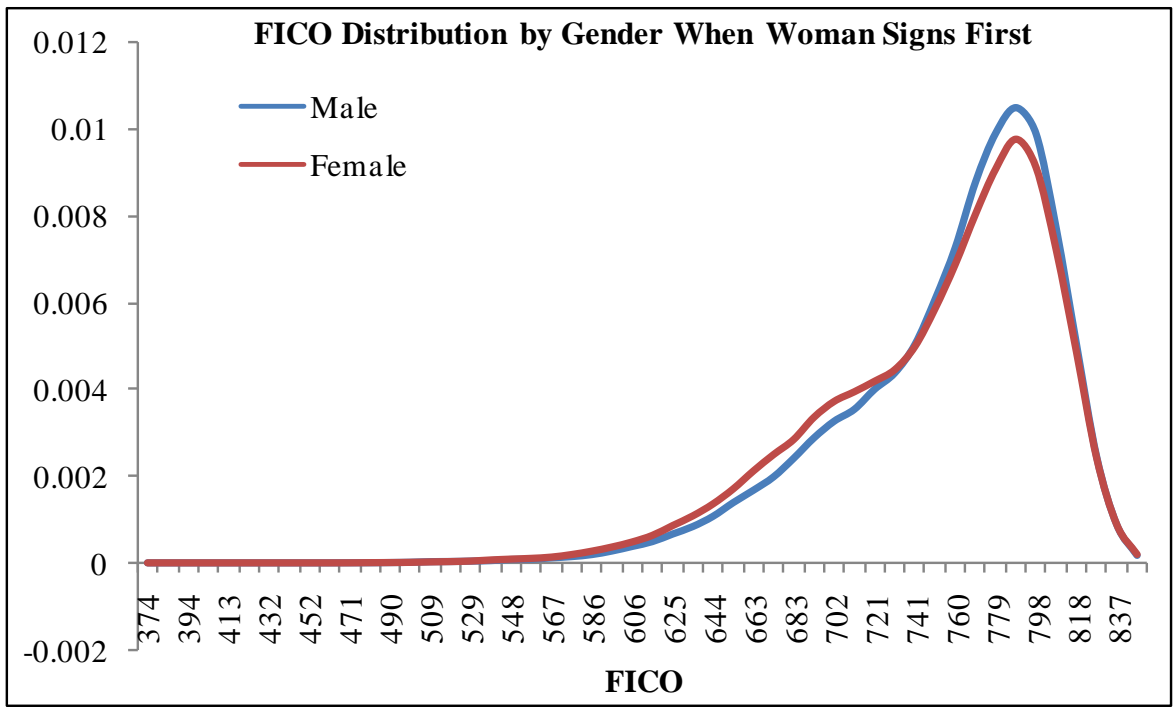


Figure 3 Gender bias and wage gap: cross-sectional evidence

This figure shows the gender wage gap defined as the ratio of men/women income (y-axis) and gender bias in signing first (x-axis) by state. The national average gender wage gap is highlighted in red line. Each point is denoted by the name of state in abbreviation.

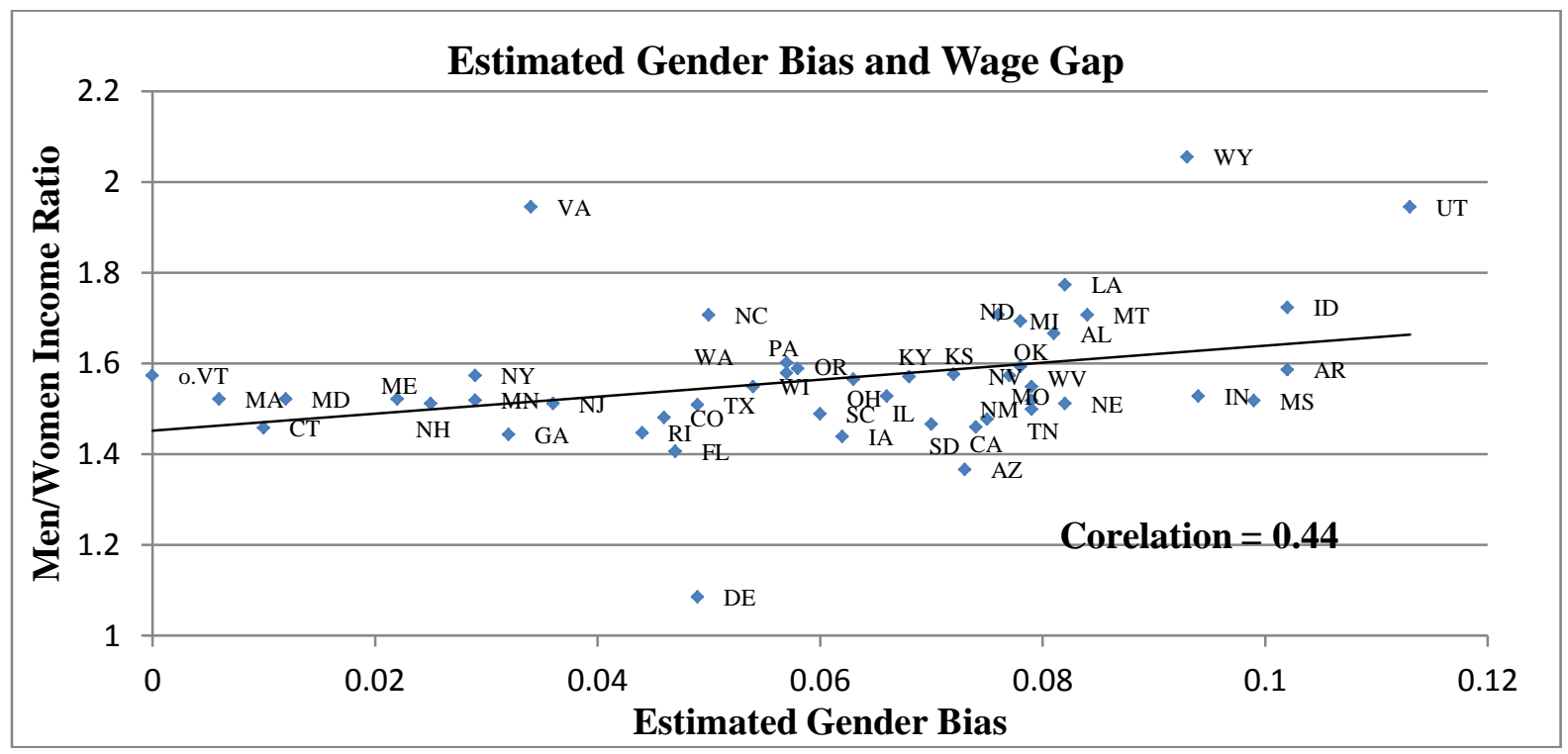

Figure 4 Gender bias and being "blue" or "red"

This figure shows gender bias in signing first (y-axis) and shares of votes Bush get in the 2004 election (x-axis) by state. Each point is denoted by the name of state in abbreviation. States with votes lower than $50 \%$ is represented by triangle while states with votes higher than $50 \%$ is by dot.

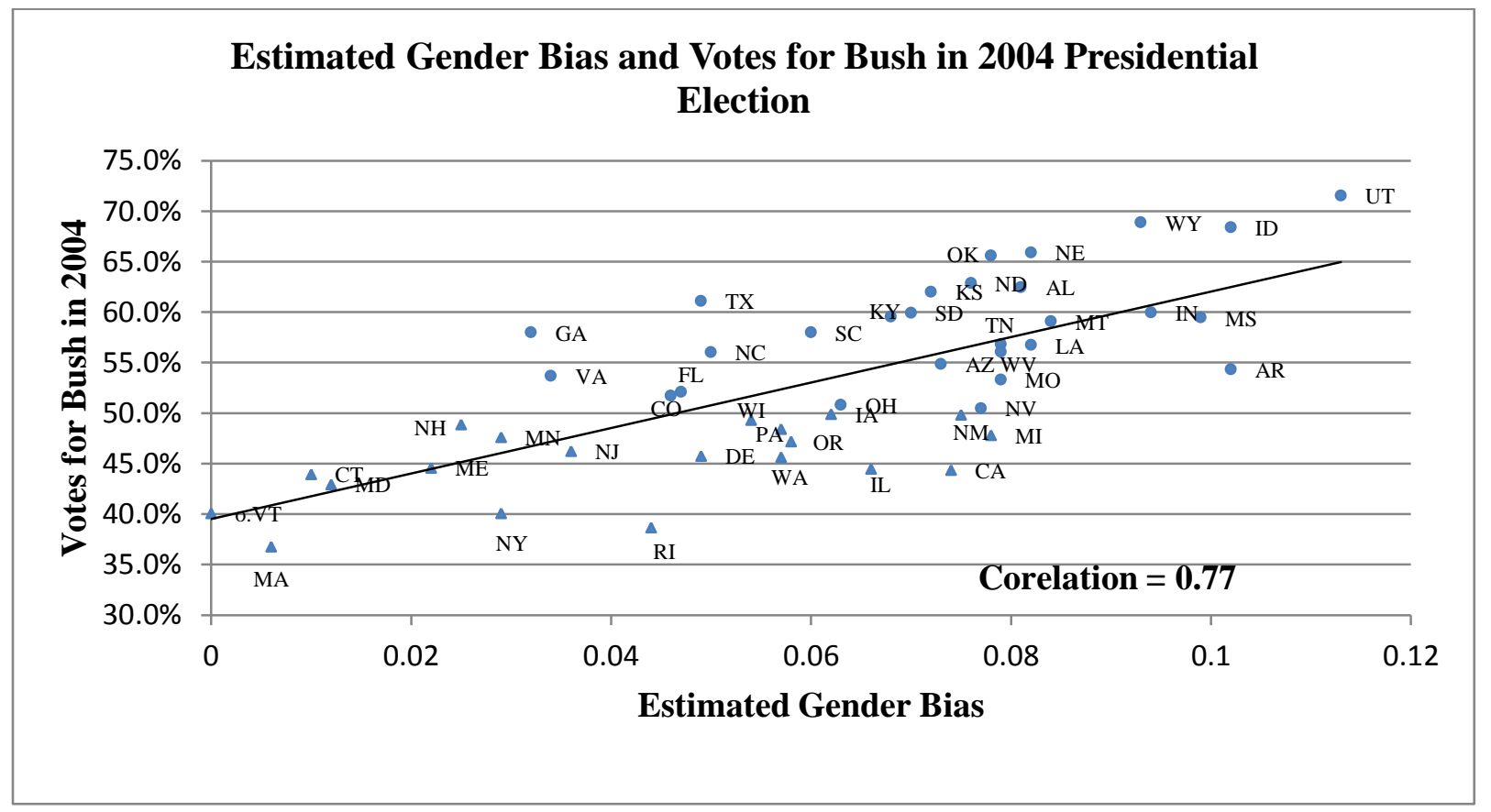




\section{Figure 5 Dynamic gender biases over time}

This figure shows the time series of estimated gender bias over time from 2004 to 2014 . The estimate in 2004 is set to zero.

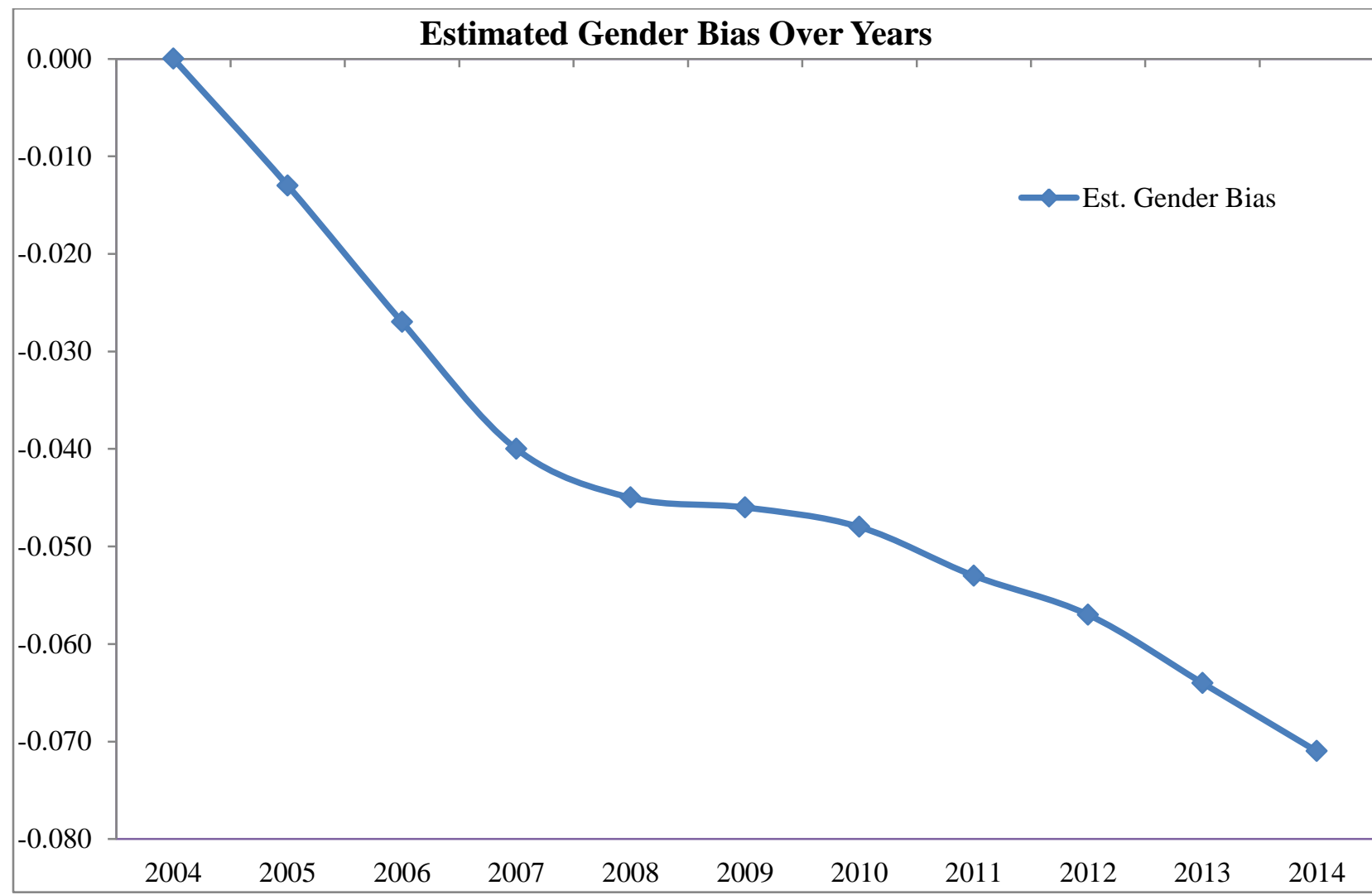


Appendix

For Online Publication 


\section{Appendix A. Variable Definitions.}

\section{$\underline{\text { Credit and Demographic Variables }}$}

Auto Number is the total number of auto trade line for the borrower as of mortgage application.

FICO is the FICO score obtained from the credit report for the borrower as of mortgage application.

Education is a dummy variable indicating whether the borrower receive education equivalent to or above College.

Age is the borrower's age.

Income is the borrower's monthly income in dollar as of the application.

Auto Number_Men is the total number of auto trade line for the man as of mortgage application.

$\operatorname{Ln}(\boldsymbol{F I C O}) \_M e n$ is the logarithm of FICO score for the man as of mortgage application.

Education_Men is a dummy variable indicating whether the man receive education equivalent to or above College.

Age_Men is the man's age.

Ln(Income)_Men is the logarithm of man's monthly income in dollar as of the application.

\section{Mortgage Variables}

$\boldsymbol{C L T V}$ is the combined loan to value ratio.

Backend is the back end ratio defined as debt to income ratio.

Note Rate is the note rate of the mortgage.

\section{$\underline{\text { Relative Variables }}$}

$\boldsymbol{D}$ (Signing First) is a dummy variable that equals one if the borrower signs first and the coborrower signs second.

Higher Income Dummy is a dummy variable that equals one if the borrower earns higher income than the co-borrower. 
Older Age Dummy is a dummy variable that equals one if the borrower is older than the coborrower.

More Autos Dummy is a dummy variable that equals one if the total number of auto trade line for the borrower is more than the co-borrower.

Higher FICO Dummy is a dummy variable that equals one if the borrower's FICO is higher than the co-borrower.

Higher Education Dummy is a dummy variable that equals one if the education level of the borrower is higher than the co-borrower.

Same Surnames is a dummy variable that equals one if the surname of the borrower is the same with his/her co-borrower.

D(Man Signing First) is a dummy variable that equals one if man signs first and his wife signs second.

Higher Income Dummy_Man is a dummy variable that equals one if the man earns higher income than his wife.

Older Age Dummy_Man is a dummy variable that equals one if the man is older than his wife.

More Autos Dummy_Man is a dummy variable that equals one if the total number of auto trade line for the man is more than his wife.

Higher FICO Dummy_Man is a dummy variable that equals one if the man's FICO is higher than his wife.

Higher Education Dummy_Man is a dummy variable that equals one if the education level of the man is higher than his wife. 
Figure A1 Distribution of CLTV by Gender when man/women signs first

This figure shows the distribution of CLTV by gender for loans with male/female as the first signer.

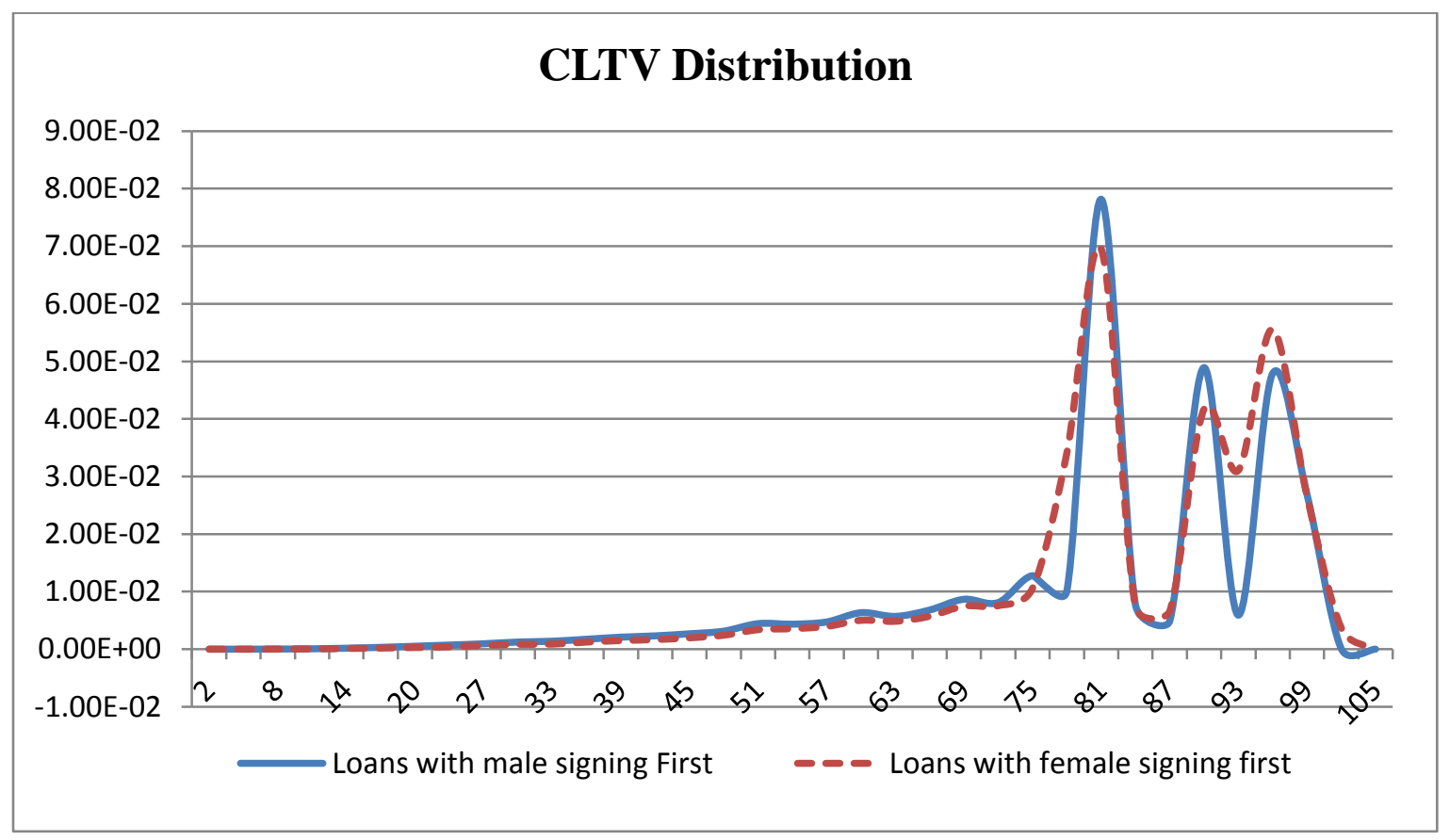


Figure A2 Distribution of Back End Ratio by Gender when man/women signs first

This figure shows the distribution of Back End Ratio by gender for loans with male/female as the first signer.

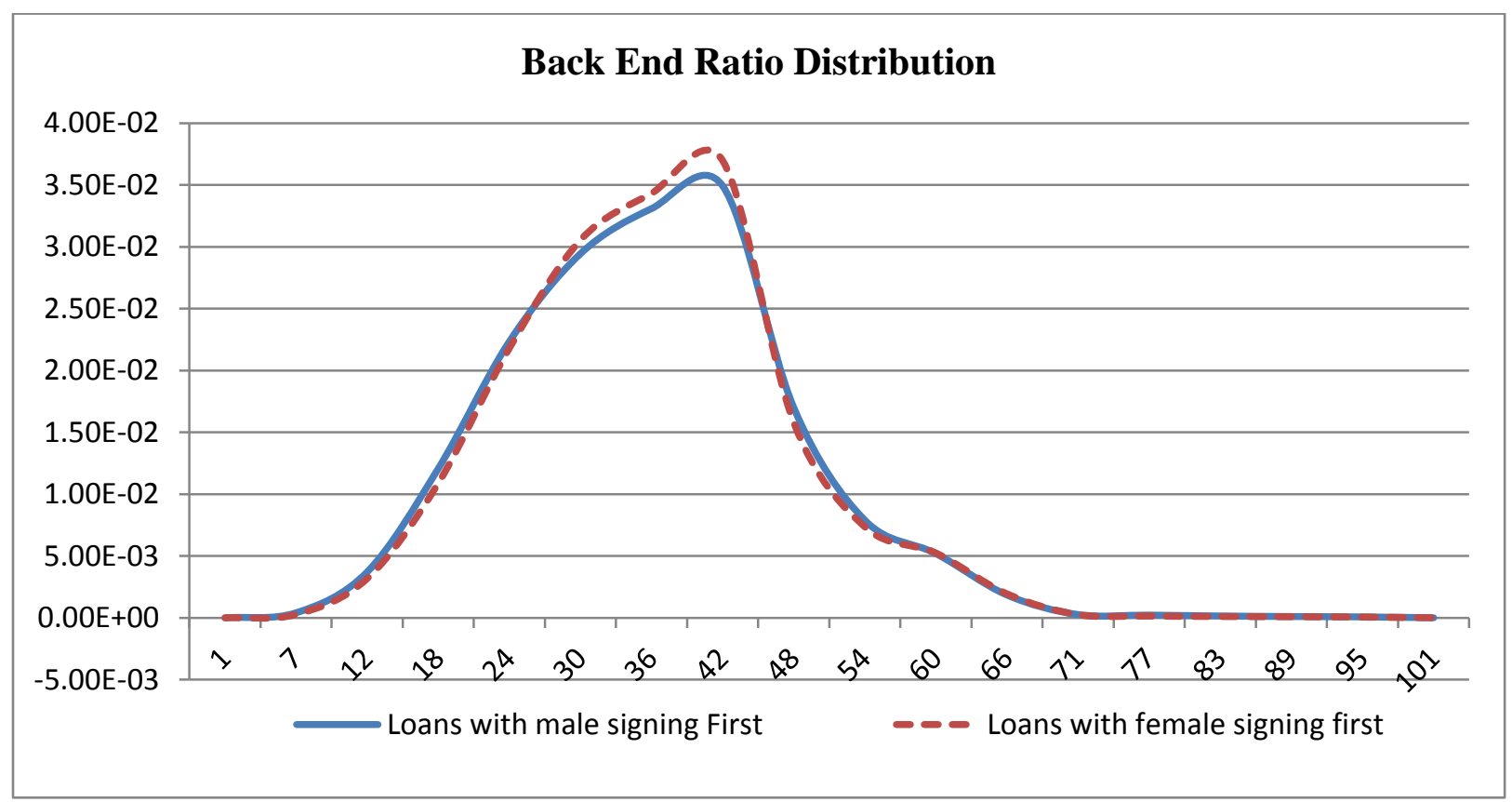


Figure A3 Distribution of Note Rate by Gender when man/women signs first

This figure shows the distribution of Note Rate by gender for loans with male/female as the first signer.

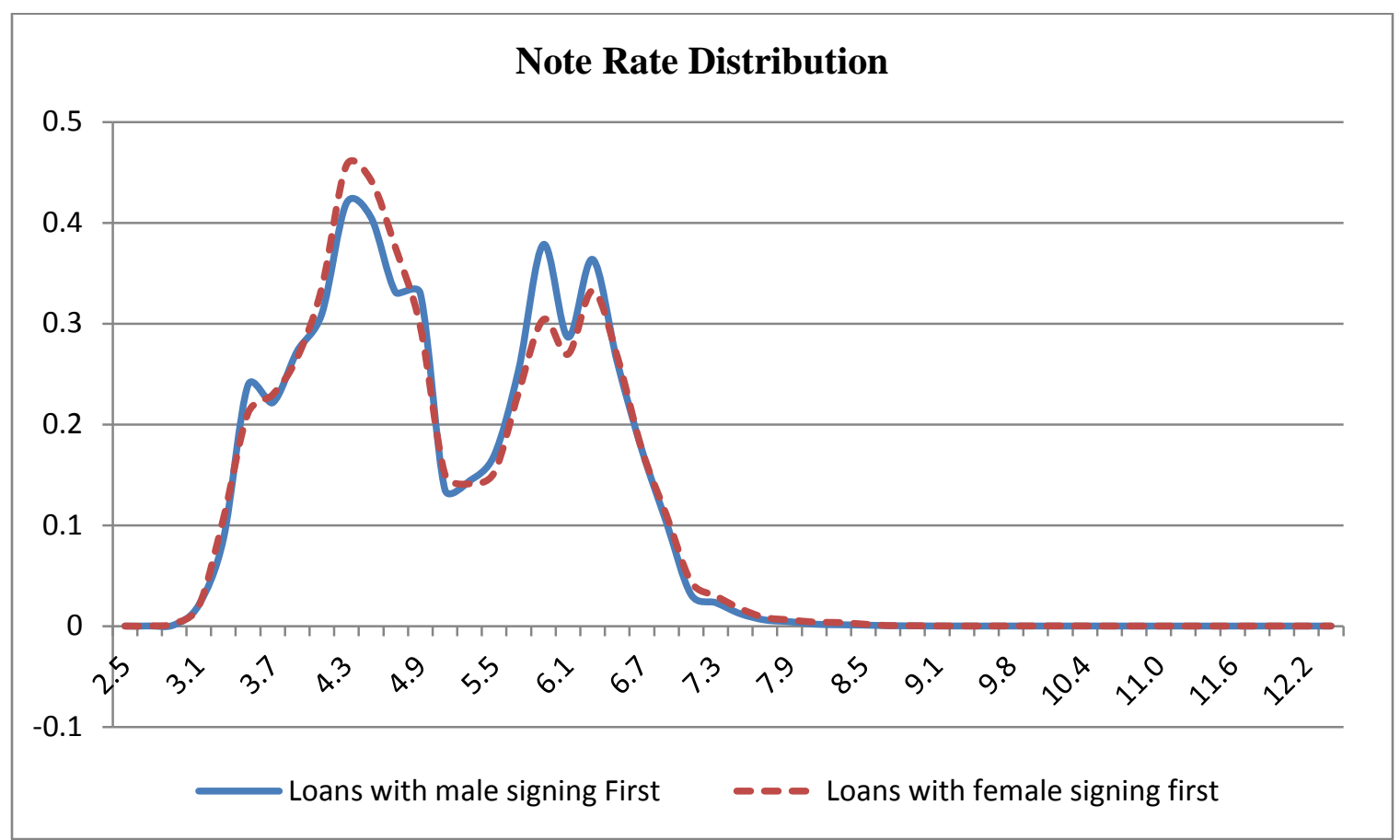




\section{Table A1: Test for the Concurrence of Signing First with Higher Income or FICO}

This table reports the test for the concurrence of signing first with higher income or FICO for the top 11 lenders in our sample. Due to confidentiality nature of the data, we keep the lenders' name anonymous and denote by 1 to 11 . Column 3 reports the percentage of male signing first for all lenders. Income Rule is a dummy variable that equals to one if the first borrower makes higher income than his/her co-borrower, zero otherwise. FICO Rule is a dummy variable that equals to one if the first borrower has a higher FICO score than his/her co-borrower, zero otherwise. Income Rule and FICO Rule are two variables to measure the concurrence between the observed first signer and the one implied by Income Rule and FICO Rule respectively. Column 4 and 5 reports the mean for both variables. If there is perfectly concurrence for certain lender, the mean value for that particular lender ought to be 1 .

\begin{tabular}{ccccc}
\hline $\begin{array}{r}\text { Lender } \\
(1)\end{array}$ & Loan Counts & \% Male Signing First & Income Rule & FICO Rule \\
\hline 1 & $(2)$ & $(3)$ & $(4)$ & $45 \%$ \\
2 & 93,903 & $89 \%$ & $79 \%$ & $45 \%$ \\
3 & 35,420 & $89 \%$ & $81 \%$ & $45 \%$ \\
4 & 35,176 & $89 \%$ & $80 \%$ & $43 \%$ \\
5 & 34,483 & $90 \%$ & $80 \%$ & $44 \%$ \\
6 & 29,564 & $90 \%$ & $82 \%$ & $45 \%$ \\
7 & 29,082 & $89 \%$ & $81 \%$ & $44 \%$ \\
8 & 22,899 & $89 \%$ & $81 \%$ & $44 \%$ \\
9 & 20,779 & $90 \%$ & $80 \%$ & $45 \%$ \\
10 & 16,081 & $90 \%$ & $81 \%$ & $45 \%$ \\
11 & 12,978 & $89 \%$ & $81 \%$ & $46 \%$ \\
\hline
\end{tabular}




\section{Table A2: Distribution of Age and Income by Gender}

This table presents the joint age and income distribution for the borrower sample. Panel A shows the statistics for age while Panel B is for income. The sample only includes different-gendered pair.

\begin{tabular}{|c|c|c|c|c|c|c|c|}
\hline \multicolumn{8}{|c|}{ Panel A Age } \\
\hline & \multicolumn{6}{|c|}{ Women's Age } & \multirow[b]{2}{*}{ Total } \\
\hline & $<=25$ & $26-35$ & $36-45$ & $46-55$ & $56-65$ & $>65$ & \\
\hline$<=25$ & 1.00 & 0.33 & 0.01 & 0.01 & 0.00 & 0.00 & 1.36 \\
\hline $26-35$ & 1.76 & 26.77 & 2.31 & 0.07 & 0.01 & 0.00 & 30.92 \\
\hline $36-45$ & 0.07 & 8.64 & 21.22 & 1.70 & 0.08 & 0.01 & 31.71 \\
\hline $46-55$ & 0.01 & 0.40 & 5.33 & 11.11 & 1.06 & 0.04 & 17.97 \\
\hline $56-65$ & 0.00 & 0.04 & 0.41 & 3.62 & 7.33 & 0.45 & 11.87 \\
\hline$>65$ & 0.00 & 0.01 & 0.04 & 0.32 & 2.24 & 3.56 & 6.17 \\
\hline Total & 2.85 & 36.18 & 29.33 & 16.84 & 10.72 & 4.07 & 100.00 \\
\hline
\end{tabular}

\begin{tabular}{|c|c|c|c|c|c|c|c|c|c|c|c|}
\hline \multicolumn{12}{|c|}{ Panel B Income } \\
\hline \multirow{11}{*}{ 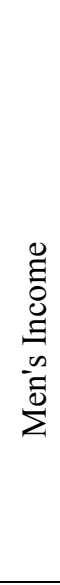 } & & \multicolumn{9}{|c|}{ Women's Income } & \multirow[b]{2}{*}{ Total } \\
\hline & & $<=\$ 1 \mathrm{~K}$ & $<=\$ 2 \mathrm{~K}$ & $<=\$ 3 \mathrm{~K}$ & $<=\$ 4 \mathrm{~K}$ & $<=\$ 5 \mathrm{~K}$ & $<=\$ 6 \mathrm{~K}$ & $<=\$ 7 \mathrm{~K}$ & $<=10 \mathrm{~K}$ & $>\$ 10 \mathrm{~K}$ & \\
\hline & $<=\$ 1 \mathrm{~K}$ & 0.04 & 0.12 & 0.29 & 0.45 & 0.51 & 0.46 & 0.42 & 0.83 & 0.79 & 3.91 \\
\hline & $<=\$ 2 \mathrm{~K}$ & 0.72 & 0.89 & 0.79 & 0.60 & 0.41 & 0.25 & 0.16 & 0.19 & 0.08 & 4.09 \\
\hline & $<=\$ 3 \mathrm{~K}$ & 1.83 & 1.69 & 2.19 & 1.62 & 0.95 & 0.53 & 0.29 & 0.31 & 0.11 & 9.53 \\
\hline & $<=\$ 4 \mathrm{~K}$ & 3.26 & 1.74 & 2.72 & 2.88 & 1.66 & 0.91 & 0.49 & 0.52 & 0.15 & 14.35 \\
\hline & $<=\$ 5 \mathrm{~K}$ & 4.12 & 1.41 & 2.14 & 2.50 & 1.96 & 1.03 & 0.57 & 0.64 & 0.20 & 14.56 \\
\hline & $<=\$ 6 \mathrm{~K}$ & 3.99 & 0.99 & 1.47 & 1.77 & 1.49 & 1.05 & 0.58 & 0.65 & 0.20 & 12.19 \\
\hline & $<=\$ 7 \mathrm{~K}$ & 3.85 & 0.66 & 0.94 & 1.17 & 1.01 & 0.76 & 0.59 & 0.64 & 0.21 & 9.84 \\
\hline & $<=10 \mathrm{~K}$ & 8.78 & 0.92 & 1.15 & 1.51 & 1.45 & 1.15 & 0.94 & 1.55 & 0.53 & 17.99 \\
\hline & $>\$ 10 \mathrm{~K}$ & 8.94 & 0.46 & 0.51 & 0.60 & 0.61 & 0.51 & 0.44 & 0.86 & 0.63 & 13.54 \\
\hline & Total & 35.53 & 8.88 & 12.19 & 13.10 & 10.05 & 6.66 & 4.49 & 6.19 & 2.90 & 100.00 \\
\hline
\end{tabular}




\section{Table A3: Power Index and Gender Bias}

This table estimates the power index and gender bias. The step 1 estimates the effect of economic power variables on signing first based on same-gender couples while step 2 regresses the residual between actual outcome of male signing first and predicted economic power from step 1 on observables for the different-gender couples. In all specifications, we include state and year fixed effects. Standard errors are clustered by states. Robust t-statistics are reported in brackets. $* *, * *$, and $*$ correspond to statistical significance at $1 \%, 5 \%$ and $10 \%$ level respectively.

\begin{tabular}{|c|c|c|}
\hline & Step 1 & Step 2 \\
\hline Dependent Variable & Power Index & Residuals $=$ male first - power index \\
\hline Sample & Same-gender pairs & Different-gender pairs \\
\hline \multirow[t]{2}{*}{ Higher Income Dummy } & $0.396 * * *$ & $0.434 * * *$ \\
\hline & $(31.96)$ & $(130.69)$ \\
\hline \multirow[t]{2}{*}{ Older Age Dummy } & $0.126 * * *$ & $0.244 * * *$ \\
\hline & $(15.04)$ & $(86.86)$ \\
\hline \multirow[t]{2}{*}{ More Autos Dummy } & $0.097 * * *$ & $0.128 * * *$ \\
\hline & $(10.10)$ & $(52.94)$ \\
\hline \multirow[t]{2}{*}{ Higher FICO Dummy } & -0.011 & $-0.061 * * *$ \\
\hline & $(-1.22)$ & $(-38.57)$ \\
\hline \multirow[t]{2}{*}{ Higher Education Dummy } & $0.023 * *$ & $-0.040 * * *$ \\
\hline & $(3.01)$ & $(-11.81)$ \\
\hline \multirow[t]{2}{*}{ Age } & $0.001 * * *$ & $0.002 * * *$ \\
\hline & $(6.95)$ & $(20.94)$ \\
\hline \multirow[t]{2}{*}{ Auto\# } & 0.002 & -0.001 \\
\hline & $(0.29)$ & $(-0.83)$ \\
\hline \multirow[t]{2}{*}{ College or Higher Dummy } & $-0.022 * * *$ & $-0.034 * * *$ \\
\hline & $(-4.49)$ & $(-31.02)$ \\
\hline \multirow[t]{2}{*}{$\operatorname{Ln}(\mathrm{FICO})$} & $0.160 * * *$ & $0.316 * * *$ \\
\hline & $(5.50)$ & (44.39) \\
\hline \multirow[t]{2}{*}{ Ln(Income) } & $0.103 * * *$ & $0.133 * * *$ \\
\hline & $(29.87)$ & $(67.62)$ \\
\hline \multirow[t]{2}{*}{ Same Surnames } & & $0.083 * * *$ \\
\hline & & $(16.11)$ \\
\hline \multirow[t]{2}{*}{ Constant } & $-1.632 * * *$ & $-3.390 * * *$ \\
\hline & $(-8.23)$ & $(-54.94)$ \\
\hline State FE & $\mathrm{Y}$ & $\mathrm{Y}$ \\
\hline Year FE & $\mathrm{Y}$ & $\mathrm{Y}$ \\
\hline Observations & 20,096 & 642,737 \\
\hline Adjusted R-squared & 0.285 & 0.448 \\
\hline
\end{tabular}

